\title{
Eliasz NAUK. Apokaliptyka, PARACElsJańsKa mistyka PRZYRODY I NARODZINY NOWOCZESNOŚCI (CZĘŚĆ DRUGA)
}

\author{
MAREK WOSZCZEK
}

\begin{abstract}
Abstrakt: Mit Eliasza Artysty (albo „Eliasza nauk/sztuk”) jest jednym z interesujących komponentów bogatej szesnastowiecznej tradycji paracelsjańskiej z marginesów poreformacyjnej ortodoksji. Sygnalizuje zaskakujący kierunek rozwoju chrześcijańskiej tradycji apokaliptycznej, ponieważ ten „Helias artium chymicarum”, mesjański Experimentator jako ludzka, stylizowana na Chrystusa postać i odpowiednik biblijnego kowala Tubal-Kaina na końcu historii, jest oryginalną transformacją żydowskiego, apokaliptycznego Eliasza w kontekście wczesnej nowoczesności tuż przed wojną trzydziestoletnią. Jest to przykład z szerszego obszaru paracelsjańskiej teoalchemii (J. Telle), którą można interpretować jako typowo nowożytną hybrydę w latourowskim sensie. Co więcej, by zrozumieć szczególny poreformacyjny fenomen mistyki przyrody (Dorn, Weigel, Khunrath, Gutman, Arndt, Boehme $\mathrm{i}$ in.), pozostający w silnym napięciu z ortodoksyjnymi teologiami, należy wziać pod uwagę, że był on wytworem tej nowej, szerokiej formacji intelektualnej, którą można nazwać przyrodniczą (albo kosmologiczna) apokaliptyką.
\end{abstract}

Autor twierdzi, że „wertykalna” (nieeschatologiczna) apokaliptyka przyrodnicza jest wczesnonowożytną forma tradycji apokaliptycznej, która w nowych warunkach społecznokulturowych przeszła transformację w formułe ,poznawania tajemnic przyrody” w złożo nym procesie renegocjacji relacji władzy i wytworzyła własny zasób motywacji poznawczych do 
aktywności eksperymentalnej, niezależnie od słabnących z czasem afektów millenarystycznych. Transformacja ta jest bardzo istotna dla zrozumienia religijnej wczesnej nowoczesności z jej immanentystycznymi, aktywistycznymi postawami i wyjścia poza jednowymiarowe dyskursy paradygmatu sekularyzacji, które zacierają albo ignorują wertykalna oś apokaliptyki i zafiksowują się na wymiarze horyzontalnym (millenarystycznym) w swoich konstrukcjach „irreligii postępu” (Löwith). Wczesną nowoczesność można lepiej zrozumieć jako rozproszony efekt związany z innowacyjnymi praktykami materialnymi, zwłaszcza medycznymi czy chemicznymi, oraz ich nowymi konceptualizacjami materii i wiedzy, gdzie filozofia, teologia, nauka o materii i społeczna rewolta wydają się nierozdzielne. Mit Eliasza nauk, dokładnie odwrotnie do powierzchownej interpretacji sekularyzacyjnej, jest jednym z symptomów zachodzącego procesu „de-eschatologizacji” przez alternatywny kierunek apokaliptyki - przenoszenia zainteresowania na przyrodę i materię jako dostępne eksploracji obiekty religijne, co wytworzyło też nowe, typowe dla nowoczesności konflikty o władzę, ale i laboratorium jako przestrzeń odkrywania tego, co ukryte w przyrodzie.

Słowa kluczowe: wczesna nowoczesność, apokaliptyka przyrodnicza (kosmologiczna), mit Eliasza Artysty, mistyka przyrody, alchemia paracelsjańska, materia, panteizm, ontologia wyrażania 


\section{Gutman i Arndt: poreformacyjna mistyka czyta alfabet przyrody}

Marzenie o ujawnieniu tajemnic przyrody i jej ukrytych zasad z elitarnego paracelsjańskiego mitu ukazuje gwałtownie rosnąca fascynację badaniami przyrodniczymi i porenesansową philosophia nova, zasilając - zanim dla teologii hieroglif Natury stał się enigmą - kształtujący się w XVI wieku innowacyjny typ mistyki, który słusznie można nazywać mistyką przyrody ${ }^{1}$. Określenie to jest jedynie pozornie oksymoronem, a byłoby bezsprzecznie, gdyby wzorcem chrześcijańskiej mistyki była katolicka, monastyczna mistyka średniowieczna czy devotio moderna, niemniej fenomen ten nie został chyba dostatecznie przekonująco zbadany. Chrześcijański mistycyzm jest standardowo rozumiany jako taki typ doświadczenia religijnego, który ignoruje lub nawet eliminuje rolę bądź wręcz realność przyrody: jest ona co najwyżej tłem, obiektem uwznioślających uczuć lub obcym elementem interferującym z bezpośredniością intymnej relacji między duszą a Bogiem. Jednak tak rozumiany ortodoksyjny mistycyzm przeszedł po renesansie i Paracelsusie transformację, którą z trudem da się wyjaśnić bez uwzględnienia głębokich przemian świadomości. Nowy stosunek do Boga i do przyrody, jak dynamika reformacji w ogóle, były wieloargumentowymi funkcjami gwałtownej zmiany układu społecznych sił w Europie i eksplozja millenaryzmu jest tylko jednym z widocznych symptomów tej niestabilności. Paradoksalnie jednak to ezoteryczny mit Eliasza nauk czy Traktat Sperbera mówią zdecydowanie więcej o tej niestabilności niż Supputatio... Lutra czy proroctwa anabaptystów, ponieważ w grze były nie tyle stare lęki przed finis mundi, endemicznie typowe dla średniowiecznej Europy, lecz konstytuująca się zupełnie nowa społeczna konfiguracja działania, wierzenia i definiowania, wytwarzajaca nowe obrazy przyrody. Kiedy nie nadchodzi koniec, na nowo trzeba myśleć początek; ale gdy dodatkowo porządek przyrody i sfera duchowa zostały gwałtownie rozerwane przez reformowana teologię, nowy punkt stabilności może leżeć tylko w wyobrażeniu ich głębokiego, niewidocznego przecięcia albo skrzyżowania. Istotnie, poreformacyjna mistyka przyrody to nowa postać apokalipsy początku, która teraz angażuje już materię jako immanentną siłę. Mistyka ta to nie żadna adaptowana na potrzeby renesansu mistyka średniowieczna, ale kolejna nowoczesna hybryda, taka jak sam paracelsyzm, warunkująca z ukrycia świeży rozmach „filozofii naturalnej” zainteresowanej deszyfrowaniem „Natury”.

W niewielu miejscach - poza oczywiście Khunrathem i Boehmem - tak wyraźnie ujawnia się po Paracelsusie próba chrześcijańskiego zrozumienia przyrody jak w dziele Aegidiusa Gutman[n]a (ok. 1490-ok. 1584). „Aegidius Gutman” to pseudonim (Robert Fludd nazywa go „Eutychius Gutman”) - do dziś nie udało się ustalić tożsamości tego autora, choć

\footnotetext{
${ }^{1}$ Najdojrzalszymi i zarazem, co zaskakujące, wczesnymi wytworami tej nowej formy mistyki idącej śladem Paracelsusa (Pagel 1979) sa z pewnością imponujące dzieła Heinricha Khunratha i Jakoba Boehmego, ale także mistyczna alchemia Gerharda Dorna i panteistyczna filozofia Valentina Weigela.
} 
z pewnością musiał należeć do paracelsjańsko-hermetycznych kręgów Szwabii i poruszać się w tamtejszych kręgach dworskich, mieszkając przez pewien czas w Augsburgu. Gutmanowi przypisano autorstwo monumentalnego dzieła Offenbarung Göttlicher Mayestat, które prawdopodobnie ukończył w ostatniej fazie życia (około 1575 r.) i które drukiem, w dwóch częściach, ukazało się dopiero w Hanau w 1619 roku u Johannesa Däscha z inicjatywy wspominanego hermetysty i teozofa Melchiora Brelera (zmarłego w 1627 roku lekarza Augusta, księcia Brunszwiku-Lüneburga), skrywającego się tu pod różokrzyżowym akronimem „M.B.M.F.C.I.” („Melchior Breler Medicus Fraternitatis Christi Infimus”, tj. „Melchior Breler, Uniżony Lekarz Bractwa Chrystusa"), z dedykacjami dla Maurycego, landgrafa HesjiKassel, i palatyna Fryderyka V, oraz z anonimową przedmową Juliusa Sperbera ${ }^{2}$. Wcześniej przez cztery dekady krążyło ono w postaci rękopiśmiennych kopii w wąskich kręgach zainteresowanych chrześcijańską ezoteryką. To ogromne dzieło w dwudziestu czterech księgach, liczące w druku ponad tysiąc stron, jest w całości rozbudowanym teozoficznokabalistycznym komentarzem do pierwszych pięciu wierszy Księgi Rodzaju. Każda księga zajmuje się tylko jednym ze słów tekstu Genesis 1,1-5, dzieląc się na rozdziały zawierające ezoteryczne objaśnienia do problemów sformułowanych w formie pytań, jakie uczeń mógłby zadawać mędrcowi-kabaliście. Gutman zaczyna więc swój komentarz od hebrajskiego „Bereshit” („Na początku”) i „Bara” („Stworzył”), przechodząc do „Elohim” („Bogowie”), „Schamaïm” („Wody”) i „Aerez” (,Ziemia”); ostatnie księgi poświęcone sa coraz bardziej wyrafinowanej interpretacji słów: „IafdeP’ („Oddzielił”), „Kara” („Nazwał”), „Iom” („Dzień”), „Lailah” („Noc”), „Eref” („Wieczór”) i w końcu „Boker” („Poranek”). Całość przypomina ni mniej, ni więcej tylko chrześcijańsko-kabalistyczny midrasz, który pragnie odsłonić sekrety przyrody ukryte w biblijnym opisie stworzenia. Autor wnika w sens poszczególnych słów oryginału Genesis (tłumacząc na przykład „Schamaiim” dosłownie jako Gewässer, „wody”, a nie zwyczajowo „niebo”), ponieważ jest przekonany - co wyraża już w tytule swojego dzieła - iż księga ta została dosłownie zapisana w takiej formie przez samego Boga, zupełnie jak przykazania wyryte na tablicach ofiarowanych Mojżeszowi.

\footnotetext{
2 [Aegidius Gutman], Offenbarung Göttlicher Mayestat, Darinnen angezeygt wird, Wie Gott der Herr Anfänglich, sich allen seinen Geschöpffen, mit Worten und Wercken geoffenbaret, und wie Er alle seine Werck, derselben Art, Eygenschafft, Krafft und Wirckung, in kurtze Schrifft artlich verfaßt, und solches alles dem Ersten Menschen, dem Er selbst nach seiner Bildnus geschaffen, uberreycht, welches dann biß daher gelangt ist (Objawienie Bożego Majestatu, w którym ukaże się, jak Bóg Pan na Początku objawił się w Słowach i Dziełach wszystkim swoim stworzeniom, i jak całe Swoje Dzieło, tego samego rodzaju, własności, mocy i działania, opisał pięknie w krótkim Piśmie, i to wszystko przekazał Pierwszemu Człowiekowi, którego sam On stworzył na wlasny obraz, który odtąd jest osiagany), Hanau MDCXIX. Zob. Gilly (1995, 11; 1986, 30; 2000, 401). Dokładniejsze omówienie tekstu daje np. Hermann Geyer (2001, cz. II, t. 1, s. 42 i n.).
} 


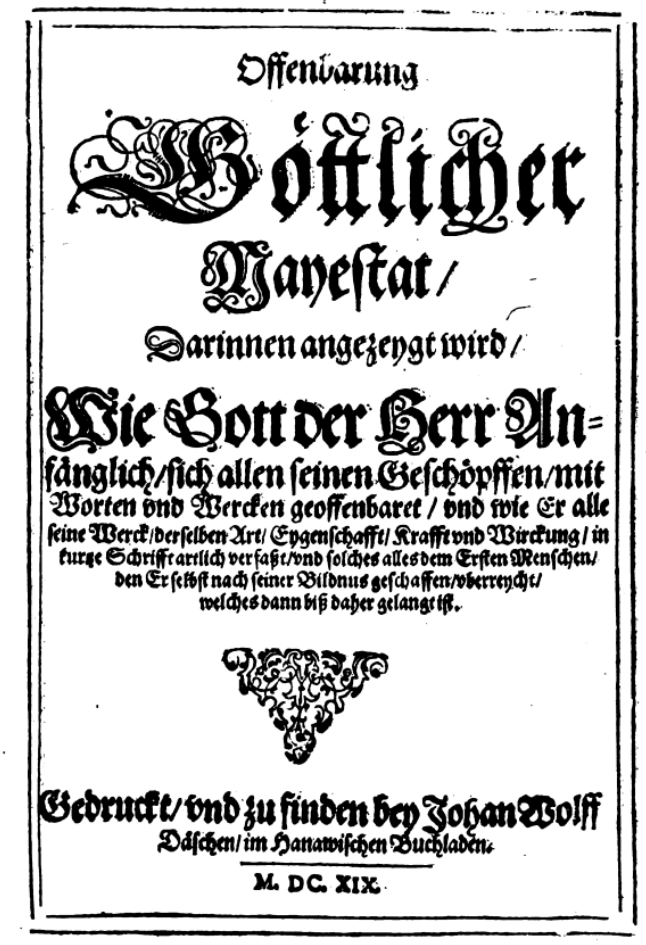

Strona tytułowa pierwszego druku Offenbarung Göttlicher Mayestat Gutmana (Hanau 1619)

Dzieło to moglibyśmy zaliczyć za Willem-Erichem Peuckertem do nurtu „panzofii” gdyby nie pewna historyczna mglistość tego pojęcia (zob. Wollgast 1993, 104) ${ }^{3}$. Offenbarung... jest jednak dziełem chrześcijańskiego teozofa inspirowanego żydowską tradycją midraszowa i kabalistyczna, zatem mamy na jego przykładzie wgląd w unikalny moment ponownego kształtowania się w XVI wieku chrześcijańskiej teozofii pod wpływem teozofii żydowskiej i renesansowej kabały (równolegle do rewolty paracelsjańskiej), co o tyle zdumiewa, iż cały czas pozostajemy w kręgu wczesnej duchowości protestanckiej, trzydzieści lat po śmierci Lutra. Jednocześnie egzegeza Gutmana jest pewnym projektem: pragnie odzyskać „mądrość Adama” i utracony ,język adamicki”, język stworzenia, by w medium przyrody nawiązać na nowo bezpośrednią łączność człowieka z Bogiem. W epoce, w której normą są zerwania, schizmy i realne walki o reżimy prawdy, również przyroda zdaje się w nie włączona jako strona poddana religijnej inspekcji: apokaliptyczny umysł, niezadowalający się samą historia, szuka pierwotnego języka przyrody, a więc reżimu jej „nieskażonej” prawdy. Prawda

3 Termin „panzofia” wolę zastapić poreformacyjnym „ezoterycznym pietyzmem”, co neutralnie oddaje charakter omawianego fenomenu drugiej połowy XVI w. i podkreśla łączność z późniejszymi jego wcieleniami w XVII i XVIII w. Standardowymi etykietami używanymi w XVI i na początku XVII w. przez luterańskich polemistów byli „entuzjaści” (Enthusiasten) i „entuzjazm” (Enthusiasmus), którymi określano wszelkie spirytualistyczne lub ezoteryczno-paracelsjańskie odchylenia od ortodoksji, co było powszechną strategia herezjologiczną (Heyd 1995, 11 i n.; Wollgast 1993, 601 i n.). Niektórzy, na przykład Khunrath, jak pietyści sto lat później, zaczęli przekornie używać tych określeń, by odebrać im ich piętnujący charakter. 
ta, co naturalne w tej sytuacji, okazała się śmiertelnym wrogiem scholastyki i fizyki średniowiecza.

Taka ezoteryczna spekulacja nie była jednak wówczas rzadkością i w pewnym sensie ukazuje typowe dla radykalnie pietystycznego świata protestanckiego napięcie, które usiłuje ona rozwiązać. Podobny, choć o wiele krótszy komentarz do sześciu dni stworzenia opisanych w Genesis, tj. Heksameronu, znajdujemy w Liber Naturae (Księdze prazyrody) Johanna Arndta, czwartej księdze jego słynnego dzieła O prawdzinum chrześsijaństwie (dalej: WCh, 160510) ${ }^{4}$, która w dużej mierze opiera się na ideach Paracelsusa, zwłaszcza jego słynnej Astronomia magna (z ok. 1537 r.), a także na Amphitheatrum sapientiae aeternae (1595) Khunratha, które Arndt podziwiał. Księga rozpoczyna się od powołania na „wielkiego proroka Mojżesza”, który przedstawić miał poprzez Genesis dwa świadectwa Boga (Zeugen Gottes): „duży świat” oraz „świat mały”, czyli człowieka, po czym autor składa obietnicę, iż objaśni to świadectwo, pokazując, jak wszystkie stworzenia świata sa „przewodnikami i posłańcami Boga” (Handleiter und Boten Gottes), które mogą doprowadzić chrześcijanina do wiedzy o nim, „zu Gott und Christo" (WCh IV, Vorrede; Arndt 1736, 638). Arndt zdaje sobie sprawę, że wielu luteran może poważnie wątpić, czy „Księga przyrody” należy w ogóle do „prawdziwego chrześcijaństwa”, więc na samym już początku odwołuje się do prologu Ewangelii Jana, a jako motto cytuje 1 List do Kolosan 1,16-17: „Ponieważ w Nim (tj. Chrystusie - podkr. i przyp. M.W.) zostało stworzone wszystko, co jest na niebie i na ziemi, rzeczy widzialne i niewidzialne, czy to trony, czy panowania, czy nadziemskie władze, czy zwierzchności; wszystko przez Niego i dla Niego zostało stworzone. On też jest przed wszystkimi rzeczami i wszystko w nim jest ugruntowane”. Wzmiankowane tu „trony”, „panowania”, „władze” i „zwierzchności” to hierarchie anielskie (Arndt 1736, 638). Następne rozdziały obejmują kolejno omówienie poszczególnych dni stworzenia, które rozpoczyna się od kluczowego dnia pierwszego i wątku „ukrytego światła” przyrody. Powołując się na Pseudo-Dionizego Areopagitę, Arndt mówi, iż oprócz światła widzialnego, słonecznego, istnieje też „inne ukryte światło (ein anderes verborgenes Licht), poprzez które poznawalna jest wewnętrzna forma stworzeń i przed którym nic nie może się ukryć” - jest to nic innego jak „wieczna mądrość Boża”, ewige Weisheit Gottes (WCh IV, 1,5; Arndt 1736, 642) i zarazem sam Chrystus (J 8,12). Przywołując wreszcie

\footnotetext{
4 Pierwsza księga ukazała się w 1605 r. we Frankfurcie nad Menem, a pozostałe trzy, z pięcioletnim opóźnieniem z powodu kościelnej cenzury, w 1610 r. w Magdeburgu. Przekład polski Samuela Tschepiusa wyszedł w Królewcu w 1743 r. nakładem oficyny Jana Henryka Hartunga: Sześ́ ksiag o prawdzinym chrzéscijaństwie, o zbawienney pokucie, serdeczney skerusze $i$ żalu za grzech, prawey wierze, swiatoblinym symocie i przystoynym prawdzinych chrzéscianów obcowaniu, oraz. Informatorium iego Biblicum i dziewiéć listów tu należacych... (znane jest też inne wydanie z 1870 roku, Cztery Ksiegi o Prawdzinym Chrześsianstwie..., w tej samej oficynie). Książka ta jest z pewnością najważniejszym i najczęściej czytanym dziełem całej luterańskiej tradycji pietystycznej zaraz po Biblii i Małym katechizmie Lutra (Trepp 2006, 44). Praktycznie większość pietystów 2. połowy XVII i XVIII wieku, od Spenera po Zinzendorfa, pozostało wiernymi tej wizji chrześcijańskiej pobożności, wybierając poszczególne akcenty: ortodoksyjne czy „budujące” w ramach kościelnej pedagogiki lub heterodoksyjne, co stanowiło „lewe skrzydło” (Schneider 2006, 154) recepcji Arndta w XVII i XVIII wieku.
} 
nowotestamentową scenę Przemienienia i blask bijący z oblicza Mojżesza po jego spotkaniu z Jahwe, mówi:

Jakże wielka będzie więc chwała (jasność/Klarheit) w nas świecąca, gdy zamieszkamy na wieczność w Bogu i będziemy na stałe u Niego! W Objawieniu Janowym 1,16 jaśnieje jak słońce oblicze tego, który dzierży siedem gwiazd; i tak samo wieczne światło, którym jest Chrystus, uchwalebni (oświeci/wird verklären - przyp. M.W.) nas owego ostatniego dnia, tak że całe ciało będzie jaśniało jak błyskawica (Mt 6,22; Łk 11,36) (WCh IV, 1,30-31; Arndt 1736, 646 i n.).

Najbardziej interesujące u Arndta wydaje się ścisłe powiązanie sofiologicznej teologii stworzenia, apokaliptyki i zmartwychwstania za pomoca motywu światła, phōs: poznanie ukrytych sfer świata to zarazem objawienie pierwotnej Mądrości Bożej-Chrystusa w duszy i zbliżenie do zmartwychwstania, które jest regeneratio, odtworzeniem stanu rajskiego. A zatem gnoza Ducha Świętego to faktyczne obudzenie w duszy światła z początków świata, dosłownie: regenerātiō, ponowne narodzenie człowieka. Ale niematerialne, kreacyjne „światło przyrody”, lumen naturae jako ukryte światła (Lichter) wszystkich bytów, to jednocześnie zgodnie z nauką Paracelsusa przedmiot badań studiującej materię alchemii oraz medycyny, o czym byli przekonani ludzie tacy jak Dorn, Khunrath czy Croll. Arndt bez wattpienia uważał siebie za dobrego luteranina, ale równie niewattpliwe jest, że taka paracelsjańska apokaliptyka przyrody sytuuje go na kursie kolidującym z całą teologia Lutra. Samo pojęcie „światła” nabiera tu typowo nowoczesnej ambiwalencji, która sygnalizuje sejsmiczne przesunięcia w obrębie filozoficzno-teologicznej semantyki - ich początki sięgaja zapewne Roberta Grosseteste’a w pierwszej połowie XIII w., którego inspirowana źródłami arabskimi metafizyka światła rozpoczyna tę protonaturalistyczno-religijną trajektorię prowadzącą do Bruna i Spinozy. U Grosseteste'a opiera się ona na neoplatońskiej metaforyce

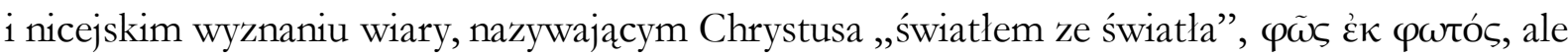
jej właściwa fascynacja to już arabska optyka geometryczna wraz ze spekulatywną fizyką albo wręcz towarzysząca astrologii kosmologia (Szulakowska 2000, 34 i n.).

Arndt, podobnie jak i Gutman, skomponował swój kreacjonistyczno-paracelsjański Liber Naturae jako swoisty chrześcijański midrasz do Księgi Rodzaju, chcąc torować drogę realizacji jakiejś przyszłej chrześcijańskiej, antyscholastycznej teozofii natury. Nie byli wyjątkami: próby tworzenia „flzyki mojżeszowej”, budowania całościowej teorii przyrody w oparciu o biblijny tekst Genesis, zaczęły pojawiać się w XVI wieku coraz częściej po Initia doctrinae physicae (1549) samego Melanchtona - mając zresztą precedensy wczesnochrześcijańskie i żydowskie, poczynając od tradycji narosłych wokół Sefer Yeșirah i Zoharu, a kończąc na inspirowanych myślą arabską spekulacjach takich średniowiecznych uczonych jak Abraham ibn Ezra (Wollgast 1993, 104). 


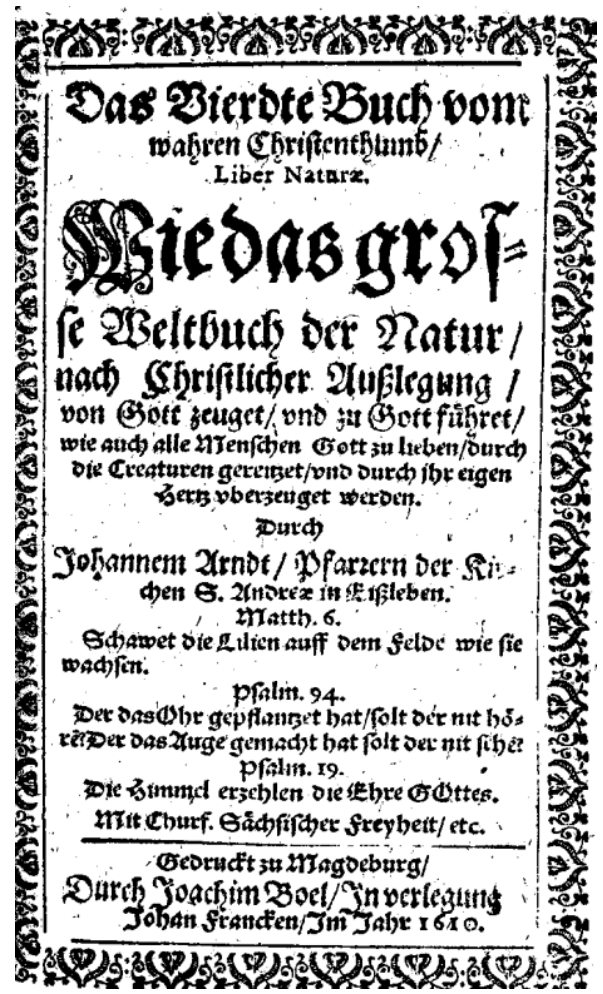

Karta tytułowa czwartej księgi (Liber Naturae) O prawdziwym chržeścijanstwie Arndta

(Magdeburg 1610)

Jednak Arndt, który nie był wykształconym teologiem (Schneider 2006, 138), wcześnie stworzył również szerszy projekt teologiczny: jeszcze przed Prawdrimym chrześcijaństwem napisał Ikonografie, niewielki traktat, w którym próbował w opozycji do kalwińskiego ikonoklazmu i opierając się w dużej mierze na ideach Paracelsusa z jego Liber de imaginibus (Paracelsus 1931) stworzyć mistyczną teologię obrazu (Arndt 1596; zob. też zwięzłe ujęcie W. Schmidta-Biggemanna 2004, 22-26). Podnosi tam obrazy i symbole do godności przejawień archetypów-idei oraz wehikułów prorockiej wiedzy, wyraźnie zaznaczając, iż stanowią one mądrość ukryta przez Boga w widzialnej przyrodzie. Charakterystyczne w jego wywodzie jest to, iż prezentację przyrody jako obrazu objawiającego Boga prowadzi on równolegle do kwestii obrazu w Biblii, objawieniach prorockich czy marzeniach sennych, co powróci u niemieckich romantyków, od Novalisa i Schellinga po Gotthilfa von Schuberta. „Znaki natury” albo „litery Boga”, sygnatury czy characteres creationis, sa tu pismem hieroglificznym zrozumiałym dla odpowiednio przygotowanych umysłów, które oglądając gwiazdy, minerały, rośliny i zwierzęta, są zdolne badać „żywą księgę Boga, którą zapisał On swoim własnym wszechmogącym palcem” (Arndt 1596, fol. 33r) ${ }^{5}$. Johann Valentin Andreae, idąc za Arndtem i parafrazując ars signata Paracelsusa, stwierdza w swojej Theca Gladii Spiritus:

\footnotetext{
${ }^{5}$ Bogaty przegląd paracelsjańskiej literatury rozwijającej teorię sygnatur w przyrodzie dają Kühlmann i Telle
} $(1996,1-40)$ 
Bóg sprawia, że w szystko to, co odkrywa ludzki umysł, podlega boskiemu tajemnemu pismu. Księga przyrody, rozpostarta przed oczami wszystkich, czytana jest i w ogóle rozumiana przez niewielu. Bóg umieścił swoje litery (characteres) i pismo (alphabetum) w różnych miejscach Pisma Świętego, podobnie jak odcisnął je również wyraźnie w godnym podziwu dziele stworzenia: na niebie, w ziemi i w żyw ych istotach (Andreae 1616, 32 i n., nr 185-187; Andreae 2003, 82-83).

Takie wyobrażenie stawia oczywiście w centrum problem ontologii naturalnej samego języka. Jak zwięźle ujął to Foucault $(2000,61)$ : „Wielka metafora księgi, która otwiera się, sylabizuje i czyta po to, aby poznać naturę, jest tylko widzialną stroną innej, o wiele głębszej przenośni, która umieszcza język po stronie świata, wśród roślin, ziół, kamieni i zwierzate”. Andreae odrzuca jednak, w duchu kabały, dawne „astralne alfabety” Babilonu i Persji jako nieaktualne już czy zafałszowane: „Zanieczyszczone pomieszaniem języki Babilonu nie maja już wiele wspólnego z tymi językami Adama i Henocha" (Andreae 1616, 33, nr 190; Andreae 2003, 82-83). Jest to istotny rys tej epoki: chce zaczynać na nowo, sięgać do początków („entuzjastyczny” moment regeneracji i odzyskania prisca sapientia) i zarazem bardzo starannie prześwietla, krytykuje i selekcjonuje przeszłość, próbując zniszczyć jej hegemonię (rewolucyjna dyskontynuacja i usunięcie zdeformowanej wiedzy). Kto nie potrafi porzucić wiedzy teoretycznej podanej przez fałszywą ortodoksję scholi, by czytać „signa signata" w samej przyrodzie, jej alfabet, ten - jak do znudzenia podkreśla Paracelsus - w ogóle nie może być ani astronomem, ani filozofem, ani tym bardziej lekarzem ${ }^{6}$. Dla prawdziwych nauk (scientiae) tak cała materialna przyroda, jak i rzeczywistość niewidzialna („was spiritualisch in allen dingen ligt' - Paracelsus 1929, 177) ${ }^{7}$ realnie stoją otworem, ponieważ nie łączy ich żadna analogia ani niejasne platońskie podobieństwo (similitudo), służące moralnemu doskonaleniu ludzi i oderwaniu ich od naturalnej immanencji ${ }^{8}$, lecz bezpośrednia ontologiczna więź, relacja niezaburzonej ciągłości wyrażania i wy twa r z a nia. Nie istnieje więc taka warstwa przyrody ani nieciagłość, której człowiek nie mógłby przeniknąć swoim poznaniem „sygnatur”. Foucault (2000, 53-55) dobrze uchwycił ten splot szesnastowiecznej episteme: jest to misterny „system podwojeń” opierający się jednocześnie na ukryciu, „mrocznej przestrzeni”, i uniwersalnym, językowym ruchu ciąłłego

\footnotetext{
${ }_{6}$ Paracelsus $(1929,175)$. Zob. analogiczne uwagi w I Księdze Opus Paramirum: Paracelsus $(1925,41)$.

7 W Paragranum Paracelsus wyraża wprost, iż „rzeczy zewnętrzne daja poznanie (erkantnus) wewnętrznych” i że „zewnętrzne niebo jest drogowskazem (wegweiser) nieba wewnętrznego”, co oznacza, że nie znalazłby minimalnego nawet szacunku dla kantowskich samoograniczeń poznawczych, funkcjonujących analogicznie do scholastyczno-tomistycznych - Paracelsus $(1924 b, 97)$. Zob. też przywołany przez Foucaulta $(2000,58)$ cytat z Archidoxis magica (ok. 1570 r.) pseudo-Paracelsusa.

${ }^{8} \mathrm{~W}$ średniowieczu relacja między różnymi poziomami bytu, w szczególności relacja podobieństwa, nigdy nie była rozważana samodzielnie: byt przyrodniczy zawsze był pochodny, a jego relacja do bytu transcendentnego objaśniana przez odwołanie do Pisma Świętego, co miało zapewniać wyższość nad nauką pogańska.
} 
ujawniania (teoria sygnatur). Paracelsus (1928b, 393), którego cytuje też Foucault (2000, 51), oświadcza: „Nie jest wola Boga, by to, co stworzył na pożytek człowieka i jemu ofiarował, pozostawało skryte".

Ale teozof Arndt idzie jeszcze dalej nawet niż Paracelsus przywiązany do oddzielania Chrystusa i etyki ewangelii od metali i przemian przyrody, a także wzniosłej magia coelestis ${ }^{9}$ od zwykłej magia naturalis. Odwołuje się do Księgi Mądrości 12,1, mówiącej o tym, iż we wszystkim obecny jest duch/tchnienie Boga ( $\pi v \varepsilon \tilde{v} \mu \alpha$ [Septuaginta] = Gottes Odem [Arndt] $)$ i dokonuje panenteistycznej reinterpretacji Pawłowej teologii: duch ten, tożsamy ze „Słowem Boga” (Logosem) jest nie tylko najgłębszą natura (Kern) kosmosu, ale przede wszystkim s i ł ą (Kraft = Arcana Paracelsusa) utrzymująca istnienie przyrody, „życiem wszystkim stworzeń” (Leben aller Creaturen $)^{10}$. Jest to semen divinum: „Słowo Boga jest najpierwotniejszym nasionem tego, co wydaje ziemia" ". Innymi słowy, luterański pietysta Arndt pragnie przekonać swoich czytelników, że dynamika i porządek przyrody, poznawalne jako tajemne „litery Boga” ${ }^{12}$, to sam ukryty w niej Chrystus! Widoczna jest w tym typie religijności, podobnie jak w omawianym wcześniej protestanckim millenaryzmie, wyraźna niestabilność: z zewnątrz prezentuje się ona jako typowy konfesyjny kreacjonizm ze sztywnym chrześcijańskim antropocentryzmem (stworzenia mają służyć człowiekowi), ale wprowadzenie materialnej przyrody jako aktorki do teologii w wersji krypto-paracelsjańskiej zaburza cały prosty model dawnej mistyki, ponieważ siły natury zaczynają wówczas zlewać się z siłami Boga - jest tylko kwestią czasu, gdy staną się tym samym. Mutacja zaczyna się od wewnętrznej deformacji; w tym przypadku nowa medycyna i nauka o materii zaburzaja maszynę teologii.

Czy ta protestancka mistyka przyrody była zdeterminowana swoją wewnętrzną logika, by ewoluować w kierunku jakiejś formy pietystycznego panteizmu, tej „ukrytej religii Niemiec" (Heine 1997, 79), której echem jest panteizm spinozjański? Odważyłbym się odpowiedzieć na to pytanie twierdząco. Ponieważ u podstaw wyobraźni paracelsjańskiej leży dynamiczna ontologia wyrażania, rodzenia i wytwarzania, a nie creatio ex nibilo, aktualizacji i analogii, ani też systemu globalnych korespondencji, odbić czy „zawojów” w stylu barokowego racjonalizmu Leibniza, wcześniej czy później „litery przyrody” jako „moce Boga" tworzą rozrastające się bez końca monistyczne uniwersum, gąszcz sił - prawie jak odbicie ówczesnej politycznej mapy kontynentu - który już na tym wczesnym etapie jest potężnym orężem radykalnej polityki przeciwko hierarchii władzy świeckiej i kościelnej

\footnotetext{
${ }^{9}$ Paracelsus $(1929,370)$ : „Also probirt sich magica coelestis in dem, was got wil, das geschicht durch das mittel, das der glauben ist".

10 WCh IV, 6,10-11, Arndt (1736, 716 i n.); zob. też Geyer (2001, cz. III, t. 2, 237-244).

11 WCh IV, 3,57, Arndt (1736, 670): „Und ist GOttes Wort der allererste Same der Erdgewächse”; zob. Geyer (2001, cz. III, t. 2, 102).

12 Arndt (1596, fol. 32v): „wünderliche Schrifft und Buchstaben Gottes”.
} 
(Wollgast 1993, 601-676). Wielu paracelsystów posuwało się o wiele dalej niż Arndt. Na przykład eksjezuita Haslmayr uważał, że Słowa Boga nie da się znaleźć w „zewnętrznych literach” Biblii, lecz jedynie w ludzkiej duszy i w wytworach przyrody, które sa „, das lebendige incarnirte Wort Gottes FIAT" (Amphitheatrum Chimicum Sacrum 1618; cyt. za: Gilly 1994, 466), co na gruncie ściśle religijnym ostentacyjnie eliminuje nie tylko rolę Kościołów, księży i pastorów, ale nawet jakąkolwiek argumentację z autorytetu Biblii. Nic dziwnego, że gdy w 1621 roku Carl Widemann i Haslmayr próbowali nakłonić Augusta, życzliwego księcia Brunszwiku-Lüneburga, by sponsorował druk kolejnych paracelsjańsko-mistycznych manuskryptów teologicznych „przeciwko błędom i fałszom papistów, luteranów i kalwinistów”, ten polecił im przekazać, że książki te „spowodowałyby w naszej teologii wielkie zamieszanie" (cyt. za: Gilly 1994, 468).

Zamieszanie było jednak już faktem i ani akademicka ortodoksja protestancka, ani kontrreformacja katolicka nie potrafily go powstrzymać. Paracelsjańskie druki i heterodoksyjna literatura mistyczna (zwłaszcza pisma Valentina Weigela), które wychodziły z oficyn Zetznera w Strasburgu, Jennisa we Frankfurcie, Knubera w Newenstatt czy Franckego w Magdeburgu krążyły już po Europie. Zaraz po śmierci Arndta, na początku lat 20. XVII wieku rozpoczęły się gwałtowne ataki na wydane przez Franckego Prawdzime chrzéśijaństwo jako dzieło głęboko heretyckie i „entuzjastyczne”, a ich głównym ośrodkiem była Akademia Teologiczna Tybingi. Swojego nauczyciela wytrwale bronił przede wszystkim Breler - ten sam, który doprowadził do wydania Gutmana. Jest jasne, że stawka to o wiele więcej niż tylko pewne artykuły katechizmu - ortodoksyjni krytycy, tacy jak Lukas Osiander Młodszy, wyczuwali atmosferę społecznej rewolucji, co może zaskakiwać, skoro mowa o „niewinnej” mistyce. Wyjaśnienie tego stanu rzeczy jest całkiem proste: zmutowana paracelsjańska metafora ukrytego „światła przyrody” istotnie funkcjonowała w ramach ontologii niedającej się pogodzić z teologia luterańską i umożliwiała nowe, antykościelne interpretacje Biblii (wzorem samego Paracelsusa), ale o wiele ważniejsze jest to, że sygnalizowała głębokie przesunięcie całego układu odniesienia, w którym interpretowane są kluczowe społeczne działania (takie jak nauczanie czy dyskursy moralne) i tworzone relacje autorytetu $^{13}$. Nie bez powodu zaczęto w radykalnych kręgach mówić o „martwym słowie”

\footnotetext{
13 Luterański scholastyk z Wittenbergi Nicolaus Hunnius, analizując mistykę Weigela w swoim Christliche Betrachtung Der Newen Paracelsischen und Weigelianischen Theology (Wittenberga 1622), wyliczał na przykład, co heretyckiego przejęła ona od Paracelsusa: „1. »Księgi papierowe« nie są środkiem, poprzez który można się czegoś nauczyć. 2. Z kazań niczego nie można wynieść. 3. Uniwersytetami i wyższymi szkołami należy pogardzać. 4. »Wywyższa on bardzo światło przyrody / i robi z niego nauczyciela także w sprawach ludzkiego zbawienia«. 5. »Poszukuje źródła swojej filozofii w owym świetle przyrody, w którym powinno się odnaleźć podstawę całej nauki«. 6. Również w boskim Objawieniu, ale bez nauczania ludzi. 7. »Uczy o podwójnym ciele, wewnętrznym i zewnętrznym«" (cyt. za: Wollgast 1993, 526). Jest oczywiste, że głównym źródłem niepokoju są tu podważane na kilku polach relacje władzy i fakt, że do gry społecznej wchodzi nowy autorytet - Natura. Zarzut nauczania o „podwójnym ciele” jednoznacznie pokazuje, że problematyczne stało się nawet pojęcie cielesności.
} 
Kościołów i nadchodzącej apokaliptycznej „nowej reformacji”, co dla władzy brzmi jak permanentna groźba rewolty. Późnym owocem tej fali nowych strategii intepretacji Biblii była zresztą na Wyspach biblijno-naukowa ideologia empirystyczna Bacona. Wskutek zbyt silnego wiązania Bacona z późniejszym angielskim empiryzmem i niedoceniania Nowej Atlantydy jego ideologia, w tym indukcjonizm, jest ex post klasyfikowana najczęściej nietrafnie. W Novum Organum wyraźnie stwierdza on, że empirycy to po prostu mrówki, co „zbieraja tylko i używają" (Bacon 1955, 125). Bacon nie był w żadnym razie empirystą w stylu locke’owskim, ale modelowym apokaliptykiem zajętym sekretami przyrody. Tym, co różniło go od luterańskich apokaliptyków, była jednak idea objęcia tych sekretów państwową kontrolą i ograniczenia spirytualistycznych źródeł możliwej rewolty społecznej.

\section{Fama Fraternitatis: arabsko-żydowska apokaliptyka kosmologiczna i chrześcijańska religia laboratorium}

Dla ortodoksyjnych, protestanckich czytelników spoza kabalistyczno-paracelsjańskiej subkultury, tak zreszta jak i dla znacznie późniejszych czytelników literatury teologicznej, ścisły związek między postulowanym teurgicznym prajęzykiem, kosmologia, historią świata, przekształcaniem materii i chrystologia pozostawał zupełnie nieczytelny albo wręcz bluźnierczy, jednak de facto był on już zarysowany jako część korpusu porenesansowej chrześcijańskiej ezoteryki. Na przykład osobliwe wyrażenia i sugestie z różokrzyżowej Fama Fraternitatis sa niezrozumiałe bez tego zaplecza. W tekście mowa na przykład o tym, iż „Rotae Mund””, „Obroty/Koła Świata”, znajdują się w „filozoficznej Bibliotece” bractwa różokrzyżowego jako „najbardziej kunsztowne” (das künstlichste) ${ }^{14}$, a zatem jest to pewna księga albo zasób wiedzy, ale w żadnym razie nie są one jak „trynitarne kręgi” z Liber Figurarum Joachima di Fiore. Jak wspomniałem, istniała w świecie arabskim wielka tradycja tahāwil sini’l-'álam, koniunkcjonistycznej astrologii epok, która wpłynęła na cała astrologię zachodnią, w tym i żydowską, a wykoncypowane przez autora tekstu „Rotae Mundi” niewątpliwie znajdują w niej swój pierwowzór. Wiedza ta jest jednak osadzona w kontekście ściśle apokaliptycznym, stąd nie chodzi tu o popularną indywidualną astrologię prognostyczna (autor deklaruje, iż „nie są nam ukazane ani nasze nieszczęścia, ani godzinka śmierci, które nam wielki BÓG przeznaczył" "15), ale o astrologię, która studiuje bieg dziejów w ramach okultystycznej oraz biblijnej kosmologii16. Fama stwierdza: „,nasze Rotae biorą swój początek

${ }^{14} \mathrm{R} 150.22$ / FFU, 86 / FFP, 56.

${ }^{15} \mathrm{R}$ 149.27-29 / FFU, 86 / FFP, 55.

16 Jest to więc znacznie rozwinięta, postperska wersja starożytnej astrologii apokaliptycznej, takiej jak ta poświadczona już przez żydowskie astrologiczno-fizjognomiczne teksty z Qumran, które skupiały się na 
w tym dniu, w którym Bóg wyrzekł swoje Fiat, i skończą się, kiedy wypowie swe Pereat ${ }^{\prime 17}$, zatem obejmują one całe dzieje świata w wielkiej skali epok i związane sa z samą struktura kosmosu, która ma być w szczegółach i osobno omówiona w ezoterycznym „Liber M.”, zawierającym mądrość-Philosophia pochodzącą od Adama, Henocha, Abrahama, Mojżesza i Salomona ${ }^{18}$ (mimo że odzyskana u arabskich uczonych in Arabia Felice). Innymi słowy, astrologia epok opiera się w „filozofii Bractwa” na jakiejś teozofii biblijnej, stąd „Liber M.”, mimo że tłumaczony $\mathrm{z}$ arabskiego „na dobrą łacinę"19, jest w istocie kosmologia kabalistyczna, którą rozwinęli Arabowie i do której, zdaniem autorów, mieli również dostęp tacy wtajemniczeni jak „Theophrastus/Theoph. B. ab Hoh.” (tj. Paracelsus). W rękopisie salzburskim (Biblioteka Uniwersytecka w Salzburgu, Cod. M I 463, 1 r-13r), pochodzacym z prywatnej biblioteki Christopha Besolda i wykonanym prawdopodobnie ręką paracelsysty Johanna Christopha Eisenmengera (bratanka Samuela „Siderocratusa”), akronim „M.” występuje w pełnej dopełniaczowej formie jako „Mysteriorum” ${ }^{20}$ - „Liber M.” jest więc „Księga Tajemnic” (lub ewentualnie „księgą »Tajemnica«”,, das Buch Mysterium” ”21). Księga ta, z jednej strony była zdobyta i przekładana przez samego „Ojca Fr. R.C.” (gdy już nauczył się arabskiego in Arabia), a z drugiej wciąż pisana „w magicznym języku”, Magische Spraache und Schrifft ${ }^{2}$, przez samych członków bractwa, miałaby więc jakieś swoje odpowiedniki w pismach kabalistów z północnej Afryki, gdzie po powrocie z Arabia Felix autor przekładu miał przebywać, poznając głębiej arabską magię, matematykę i fizykę - to, co i najbardziej pogańskie, i najbardziej fascynujące. Księgę tę ludzie mają i czytać, i sami pisać, co jest typową paracelsjańską ambiwalentną zasadą związaną z nierozdzielnością praktyki i teorii.

Fama aż dwukrotnie przywołuje motyw „Sphera” czy „Globus”, w którym wszystko „zbiega się ku centrum” ${ }^{23}$ i który stanowi tajemny klucz do Biblii oraz poznania przyrody. Idea opieczętowanej literami i obracającej się sfery jako podstawy permutacyjnej konstrukcji kosmosu stanowi rdzeń najbardziej prawdopodobnego pierwowzoru „Liber M.” w Sefer Yeșirah, który luterańscy teozofowie musieli znać albo, co mniej prawdopodobne, z pierwszego przekładu Postela z 1552 roku (Abrahami Patriarchae Liber Jezirah...), albo ze

rozpoznawaniu indywidualnego moralnego charakteru i przeznaczenia do zbawienia kandydatów na członków sekty, zob. np. Alexander (1996, 385-394).

17 R 147.14-16 / FFU, 82 / FFP, 54. Rotae obejmuja całe epoki świata, ponieważ, jak deklaruje autor, „zegar Boga bije co minuta, kiedy nasz zaledwie co godzinę (R 147.17-18: da unsere kaum die gantze stunden)".

18 Tak przedstawiany rodowód wiedzy o przyrodzie, w szczególności kosmologii, nie był niczym wyjątkowym - jeszcze pół wieku później w taki sam sposób o swojej fizyce myślał Newton: McGuire i Rattansi (1966, 122 i n.), Woszczek (2009, 151-170).

19 R 141.11-13 / FFU, 74 / FFP, 51.

${ }^{20} \mathrm{FFU}, 86$ (= R 149.25).

${ }^{21} \mathrm{FFU}, 80$ (= R 146.28).

22 R 146.23-24 / FFU, 80 / FFP, 54. Zob. Andreae (1616, 33, nr 189; 2003, 82-83).

${ }^{23} \mathrm{R}$ 144.15-16, 159.17-19 / FFU, 78 i 98 / FFP, 52 i 60. 
słynnej antologii Pistoriusa Artis Cabalisticae z 1587 r. (Sefer Yeșirah umieszczona tam była pod tytułem Liber de Creatione), zawierającej też zresztą dwa główne dzieła Reuchlina. W Sefer Yeșirah, zwanej też w niektórych starych rękopisach מפר אותיות (Ksiega liter), czytamy na temat konstrukcji wszechświata:

Dwadzieścia dwie podstawowe litery powiązane są ze sferą (Postel: literae fundamenti compactae sunt cum Sfaera / Pistorius: litterae, Fundamenta, collocatae in sphaera) w 231 (bram), a koło obraca się tam i z powrotem (Postel: revertitur circulus ante \& retro / Pistorius: sphaera directe rotata... retrograda econverso). Oto schemat do objaśnienia tak w odniesieniu do dobra i tego, co cnotliwe, jak i zła oraz tego, co przeklęte. W ten sposób (Bóg) wyważał je i naprzemiennie je łączył: Alef ze wszystkimi i wszystkie z Alef; Beth ze wszystkimi i wszystkie z Beth. I (przez te obroty) każda rzecz jest sprowadzona do tych 231 bram, i z nich wyprowadzone tak wszystko, co można wypowiedzieć, jak i każde stworzenie w oparciu o nie formowane, wszelka forma wyw odząca się z jednego Imienia (Postel: sic res regreditur ad 231. portas, \& invenitur omnis locutio \& omnis creatura formatione procedens ex ipsis, \& invenitur tota Formatia procedens ex nomine uno / Pistorius: ita rotando singulas per omnes, resultant Ianuae ducentae triginta \& una. Et omnia Idiomata \&o omnis creatura ex illis...) (Postel 1552, b. pag., i Liber de Creatione 1587, 870; tlum. - M.W. $)^{24}$

Opis ten odnosi się do tworzenia wszystkich bytów i substancji, formatio mundi, poprzez dwójkowe kombinacje czy permutacje 22 liter hebrajskiego alfabetu, co daje 231 „,bram”, שערים (= łac. portae/ianuae), a więc oferuje klucz do kosmologii za pomoca spekulacji na temat prajęzyka. Hebrajskie גלגל z oryginału można przełożyć jako „koło, krag” (rota/circulus/orbis), „sfera” (sphaera) lub „cykl, obrót” (orbis/revolutio), na przykład planetarny (sfaera in anno, jak Postel tłumaczy we fragmencie $6.2 \mathrm{w}$ odniesieniu do Słońca), i wszystkie te znaczenia są wykorzystane w oryginalnym tekście. „Obroty”, które tu się pojawiaja, to jednak coś o wiele pierwotniejszego niż koniunkcyjne cykle planet rządzące następstwem epok: siedem hebrajskich liter podwójnych (duplices) symbolizuje siedem planet, służąc do formowania gwiazd, firmamentów i ziem, zaś dwanaście prostych (simplices) - dwanaście znaków Zodiaku i miesięcy, a ich logika, „obrót (krag) i środek” (Postel: orbis \& cor), jak się wyraża Sefer Yeșirah 6.1 (גלגל ולב), to ukryta logika architektury i z a r a z e m historii kosmosu. Bóg pieczętował tymi literami-siłami i jedno, i drugie: „wa ży 1 je (שקלן; podkr. - M.W.),

\footnotetext{
${ }^{24}$ Nowa edycja krytyczna thumaczenia Postela: Klein (1994). Tom Pistoriusa zawiera w tytule fraze „tajemna teologia i filozofia" (tzn. kabała), zaś Fama krytykuje rozdzielanie i przeciwstawianie filozofii i teologii (R 159.12-13 / FFU, 98 / FFP, 60), więc jej autor może tu nawet odwoływać się wprost do tej antologii jako inspirującego go źródła.
} 
przekształcał, łączył, i tworzył duszę (נפש) każdej rzeczy istniejącej i mającej zaistnieć" Późniejsza Confessio w rozdziale 9. bez dwuznaczności już wyjaśnia, iż chodzi tu o „characteres, litery i alfabet, jakie Bóg tu i ówdzie udzielił w Świętej Biblii, wdrukował je także cudownemu stworzeniu nieba i ziemi”, i że jest to „język naszych praojców Adama czy Henocha”, a zatem język kreacji albo formowania świata to po prostu język hebrajski, do którego klucz ukryty został wraz z biblijnym pomieszaniem języków. Ideę tę, wyrażoną otwarcie przez Paracelsusa (1928b, 397 i n.), głosił też Postel, dla którego język hebrajski był jedynym właściwym medium komunikacji między Bogiem i stworzeniem, stąd jego odzyskanie miało być wręcz koniecznym warunkiem odnowy świata i zbudowania uniwersalnej religii pokoju. Inspirowany kabała późniejszy spekulatywny paracelsyzm, a w jego ramach Gutman, Khunrath i Boehme, przejął tę doktrynę, utożsamiając stwórcze „Fiat” zarazem ze SłowemLogosem i kosmiczną materia pierwsza (zob. np. Walton 2015, 194 i n.). To ostatnie nie było żadną ekstrawagancja, lecz konsekwentnym rozwinięciem omawianego wcześniej pomysłu teologicznego rzuconego w Opus paramirum przez samego Paracelsusa (i średniowiecznej idei Dawida z Dinant). Jest to też kolejny przykład - po micie Eliasza Artysty - zaproponowanej mimochodem idei, która z czasem rozrasta się w dojrzałą hybrydę, otwierając drogę do chrześcijańsko-panteistycznej teologii.

Należąca do tego samego nurtu Fama chrystianizuje tę kabalistyczną kosmologię w duchu Reuchlina, Postela i Khunratha, ponieważ poprzez aluzję do "Iesus ex omni parte” („Jezusa ze wszystkich stron”) i jego licznych „membra” („członków”) jako „obrazu Ojca”27 dobitnie zaznacza, iż owa „filozofia Adama” jest właściwie niczym innym jak kosmiczna chrystologia, jak na Postelowskiej, kabalistycznej rycinie Ukrzyżowania z druku słynnej edycji

${ }^{25}$ Liber de Creatione (1587, 870, cap. 2): „Viginti duas literas (...) ponderavit, transmutavit, composuit, \& creavit cum illis omnem animam creatam \& creandam". Zob. więcej np. w: Schmidt-Biggemann (2004, 220 i n.).

${ }^{26}$ Confessio Fraternitatis: R 218.3 / FFG, 73 / FFP, 70. Paracelsjańska terminologia ,,characteres dem wunderbabren Geschöpff eyngedrucket" pochodzi bezpośrednio od Arndta, który z kolei rozwiną ja pod wpływem lektury Amphitheatrum... Khunratha (zob. np. Arndt 1596, fol. 32v, gdzie ten ostatni nazywany jest „ein fürtrefflicher Philosophus und Naturkündiger'); na tej metaforze opiera się też cała Offenbarung... Gutmana. Na temat kabalistycznych wyobrażeń przyrody jako zapisanej księgi, imperatywu jej „czytania” i ontologizacji literelementów zob. np. Geyer (2001, cz. II, t. 1, 15-60), von Stuckrad (2010, 89-113) i Vickers (1984, 105 i n.); zob. Foucault $(2000,50-70)$. Von Stuckrad $(2010,92)$ słusznie zauważa, że nawet tak wytrawny historyk idei jak Blumenberg w swej słynnej Lesbarkeit der Welt (1979) ostentacyjnie ignoruje rolę kabały i paracelsjańskiej teozofii natury w ewolucji metafory „czytania świata” w kierunku immanentystycznej apokaliptyki, co wymownie ilustruje jednostronność filozoficznych konstrukcji samej nowoczesności. Ta kabalistyczna metaforyka powraca jeszcze okazjonalnie nawet w XX wieku, na przykład u wczesnego Waltera Benjamina w jego Über Sprache überhaupt und über die Sprache des Menschen z 1916 r. (w: Benjamin 1991, 140-157), tekście zwróconym - w swoiście paracelsjańsko-romantycznym duchu - przeciwko „mieszczańskiej koncepcji języka”. Nic dziwnego, że Benjamin, jak Gutman i Arndt trzy stulecia przed nim, zwraca się, zarysowując swoje teologiczne przedsięwzięcie, ku Księdze Rodzaju.

${ }^{27}$ R 159.10-11 / FFU, 98 / FFP, 60. 
syryjskiego Nowego Testamentu Postela-Widmanstadta ${ }^{28}$ albo na analogicznej, zdumiewającej rycinie „róży świata” z Amphitheatrum... Khunratha. Dekadę po Famie ta

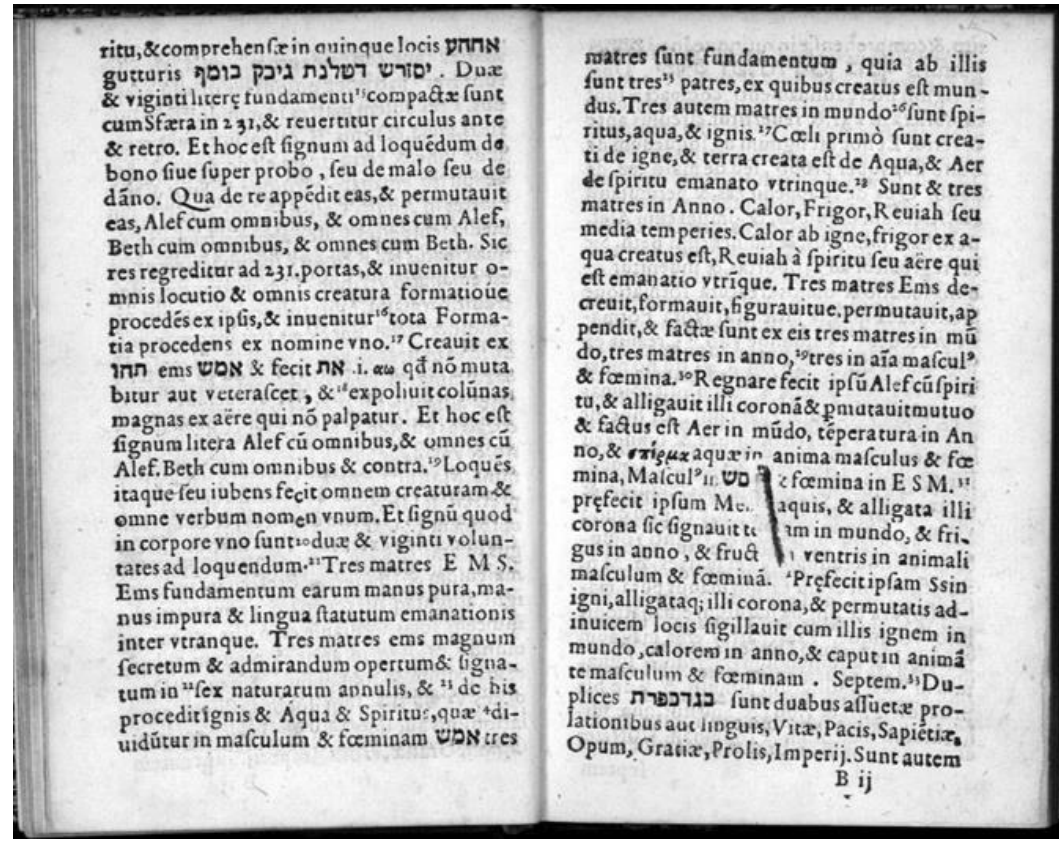

Dwie strony z druku łacińskiego przekładu Sefer Yeșirah autorstwa Postela, Abrahami

Patriarchae Liber Jezirah... (Paryż 1552). Po lewej u góry kosmologiczny fragment mówiący o obrotach sfery pieczętowanej binarnymi kombinacjami hebrajskich liter

różokrzyżowa idea pojawiła się u Boehmego w jego monumentalnym komentarzu do Księgi Rodzaju, gdzie ku zdumieniu czytelnika wspomina, iż drugie Świadectwo otrzymane przez Mojżesza na Synaju (Wj 34, 1-4; 27-29) nie zostało mu dane ponownie na dwóch kamiennych tablicach, שני־לחת אבנים, lecz w postaci pokrytej Pismem kamiennej k u li, ,eine andere Schrifft auff eine KugeP”, „oznaczającej drugiego Adama (Chrystusa), który winien przywrócić tego pierwszego" (Böhme 1682, 108, cap. 18, par. 20) ${ }^{29}$. Jest to zresztą oryginalna

28 Wraz z orientalistą i kanclerzem Dolnej Austrii Johannem Albrechtem Widmanstadtem Postel przygotował i opublikował w Wiedniu w 1555 r. w nakładzie tysiąca egzemplarzy pierwsze drukowane, przeznaczone do celów liturgicznych wydanie syryjskiego tekstu Nowego Testamentu (z wyjątkiem Apokalipsy i czterech listów apostolskich), którego manuskrypty przywiózł ze sobą wcześniej z Damaszku: Liber Sacrosancti Evangelii De Iesu Christo Domino \& Deo Nostro, (...) characteribus et lingua Syra, Iesu Christo vernacula, Divino ipsius ore consecrata et a Ioh. Evangelista Hebraica dicta... Zob. np. Kuntz (1981, 115-117) oraz przede wszystkim fundamentalne studium Roberta J. Wilkinsona (2007); tam na temat kabalistycznej ryciny Postela: s. $182-185$. Więcej informacji na temat Widmanstadta i jego edycji również w: Metzger (2001, 52 i n.).

${ }_{29}$ Boehme mówi wprost, że drugie objawienie Jahwe na Synaju, po potrzaskaniu pierwszych tablic, nie było w istocie Prawem, lecz nową wiedzą - o Chrystusie, „chrystozofią”. Jeszcze przed nim autor Famy twierdzi, że wiedzę tę, choć zniekształconą, posiadali także Arabowie w postaci kosmologii i alchemii, które ciemna Europa musiała ze Wschodu dopiero odzyskać. Postel z kolei opisał własną mistyczną wizję hebrajskich liter rozmieszczonych na sferze niebieskiej i generujących formy wszystkich rzeczy w swoim komentarzu dołączonym do Liber Jezirah. 
chrześcijańsko-kabalistyczna interpretacja św. Pawła, który przeciwstawia w 2 Kor 3 „służbę śmierci, wyrytą literami na tablicach kamiennych” i „umysły otępiałe” nowemu poznaniu

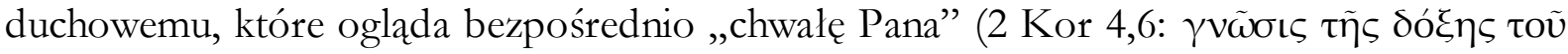
$\theta \varepsilon$ oṽ), bez zasłony. Ostra opozycja „żywych liter” i całej przyrody jako „żywej księgi/objawienia Boga" (tj. Chrystusa-światła, którego rozproszone członki-membra pieczętują kosmos) oraz „martwych liter” i archaicznych „papierowych ksiąg” 30 jest nie tyle zwykłą metafora, co manifestacja zachodzącego kryzysu i gwałtownego przesunięcia czy ugięcia kierunków zainteresowań, wskazywanych przez religijne epitety „żywy” i „martwy”. Figulus nazywa na przykład kosmos „wielką sferyczną księga przyrody” opisana „pieczęcią Trójcy Świętej” i dosłownie rozpościerająca się przed ludzkimi oczyma ${ }^{31}$. W kwestii tej zgodziliby się z nim bez wahania tacy uczeni ze środowiska tybingeńskiego jak Kepler, który dostrzegał ślad Trójcy Świętej w całej organizacji kosmosu, gdzie sfera gwiazd reprezentowała Chrystusa, a Słońce - Boga Ojca (Kepler 1596, 21). Okazuje się, że

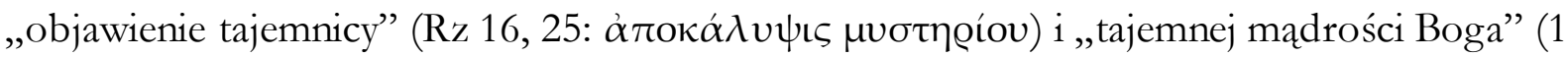

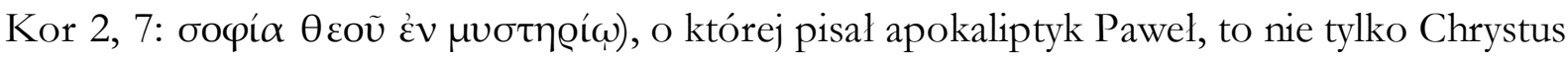
znany z ewangelii, ale niewidzialny dla zmysłów „chymiczny (ognisty) Chrystus” działający we wszechświecie, co zmienia całą teologiczną kartografię i stanowiło na przykład fundament skrywanej ariańskiej chrystologii Newtona.

Możliwość przyswajania tej przyrodniczo-hermetycznej teozofii przez luterańską mistykę pojawiła się głównie dzięki dyskretnemu wysiłkowi paracelsjańskiego pietysty Arndta, którego w Tybindze podziwiali Andreae, Besold, Schickard i inni. W szczególności Besold, korespondent Arndta, był orędownikiem jego wizji mistycznej reformacji, czego wyrazem jest zadedykowana Arndtowi filozoficzna rozprawa De verae Philosophiae fundamento Discursus, wydana przez Celliusa w Tybindze w 1618 roku (zob. np. Gilly 1986, 134-138). Podobnie też Andreae, mniej więcej od 1616 r., już jako początkujący diakon i pastor pomocniczy w Vaihingen, propagował idee z Prawdzivego chrześsijaństwa Arndta, swojego - jak sam mówił „duchowego ojca”, mając nadzieję na ukształtowanie nowego typu „chrześcijańskiego obywatela", civis christianus - pietysty prowadzącego eksperymentalne badania przyrody, uprawiającego matematykę i tworzącego nowy świat przyszłości. Bractwo takich cives z marzenia Andreae’i jest luterańsko-akademicką wersją międzynarodowego chymicznego

30 Zob. np. w: Arndt (1596, fol. 33r). Podobnie przyroda jako „żywa księga Boga” z „żywymi literami” w opozycji do ludzkich ksiąg i liter jako „martwych cieni” np. w: WCh IV, 3,14 (Arndt 1736, 658).

31 Figulus (1608a, b. pag. [fol. XXI]): „,das grosse mächtige Circkelrunde Buch der Natur (...) geschrieben (...) mit dem Finger Gottes durch Sacrum Uni Trinitatis Signaculum”. W pierwotnej żydowskiej wersji apokalipsy z Hebrajskiej Księgi Henocha, z pewnością wcześniejszej od Sefer Yeșirah, „literami stworzenia” opisywana jest „palcem Boga jak piórem ognistym” korona na głowie anioła Metatrona, „Księcia Oblicza” - są to „litery, przez które stworzone zostało wszystko, co konieczne w świecie i cały porządek kosmosu" (3 Hen 13, 1). W wersji chrześcijańskiej stojącego przy Bogu Metatrona zastępuje Chrystus. 
„Towarzystwa Filozofów” ze Statutów Michała Sedziwoja „Kosmopolity”. Waga poznawanych sekretów przyrody najwyraźniej miała tu jeszcze na początku współgrać z elitarnością stowarzyszeń i wymaganą głębią życia duchowego, o czym nie było już oczywiście mowy w pierwszej połowie XVIII wieku. „Generalna reformacja” przez czytanie „żywej księgi Natury” jest na tym etapie ideałem w pełni apokaliptycznym. Poznanie „anatomii wszechświata” (anatomia Macrocosmi) łączy się bezpośrednio z chemicznym badaniem metali w mikroskali laboratorium i jest to działalność wymagająca najwyższych kompetencji naukowych:

... [Badanie przyrody jest prowadzone] przez ludzi, którzy nie są jak zwierzęta pociagowe zaprzężone do bezsensownej roboty, lecz takich, którzy zostali uprzednio wyuczeni precyzyjnej wiedzy fizycznej (rerum physicarum cognitione) i którzy z tego powodu znajdują przyjemność w z nurzaniu się we w nętrze [wnętrzności] przyrody (inter naturae viscera). Jeśli nie słuchasz argumentów rozumowych i ni e zgłębiasz anatomii wszechświata, uważają oni, że nie warto niczego ci mówić ani niczego demonstrować. Jeśli nie rozstrzygasz problemów eksperymentami, ani nie naprawiasz niedostatków wiedzy naukowej za pomocą odpowiednio dostosowanych instrumentów, nie masz dla nich nic wartościowego. Wierz mi, gdyby jakiś sofista chciał tu czegoś dowodzić, to chyba na prawach żartu - do tego stopnia bardziej cenią oni rzeczy niż [puste] słowa. Tutaj można poznać i posłuchać o prawdziwej, autentycznej chemii (...). Krótko mówiąc, oto jest praktyczna nauka o materii (Physica practica). (Andreae 1619, 41 i n., tłum. i podkr. - M.W.)

A jednak literacki wybór Maroka jako źródła wiedzy z zakresu matematyki, fizyki i magii dla wielkiej odnowy-instauratio nauk i zarazem nowej (jeszcze głębszej - po pierwszej, nieudanej) reformacji chrześcijaństwa ${ }^{32}$ jest jednym $z$ zaskakujących fragmentów legendy z Famy Fraternitatis. Przez dwa lata „Ojciec C.R.” miał przebywać w Fezie i studiować z tamtejszymi uczonymi, choć „ich Magia nie była całkiem czysta, a również ich Kabałę skalała ich religia" ${ }^{33}$, a nawet, jak sugeruje tekst, uczestniczyć w jakichś praktykach rytualnomagicznych $^{34}$. Manifest szkicuje powrotną droge „C.R.”, przynoszącego jak Eliasz nauk zapóźnionej, podzielonej Europie nową wiedzę („,nowe artes, dzięki którym można by w pełni odnowić wszystkie rzeczy”, a nawet informacje o „nowych roślinach, nowych owocach

\footnotetext{
${ }^{32} \mathrm{Na}$ temat dwóch reformacji i trzeciej, paracelsjańskiej, tak jak postrzegano je w 2 pol. XVI i w 1 poł. XVII w. (w opozycji do historiografii XX-wiecznej), zob. np. Gilly (1997, 60 i n.).

33 R 142.18-20 / FFU, 76 / FFP, 52.

34 R 142.11-14 / FFU, 76: „Zu Fessanum nun oder Fez, machet er kundschafft zu den, wie man sie zu nennen pflegt, Elementarischen Inwohnern, die ihme viel des ibrigen eröffneten...” Terminologia „mieszkańców światów elementarnych (scil. żywiołów)" jest oczywiście paracelsjańska.
} 
i zwierzętach" $\left.{ }^{35}\right)$ z Maroka przez Hiszpanię do Niemiec, skąd wyruszył. Dla uczonych europejskich - „pozornych mędrców”, Naßweysen - jednak „była to sprawa śmieszna”, podważająca autorytet wielkiej tradycji (Arystotelesa, św. Tomasza) i niebezpieczna, wedle konserwatywnej maksymy: „Niech reformuje się ten, który kocha niepokój" 36.

W istocie, fuzja astrologiczno-kosmologicznej oraz magicznej interpretacji Sefer Yeșirah nastąpiła właśnie w średniowiecznym Maroku w środowiskach kabalistów, którzy studiowali ja razem z tekstami ze zbioru ספר רזיאל (Ksiegi Raziela, pierwszego w Europie ezoterycznego dzieła żydowskiego skompilowanego po łacinie, być może w Toledo, jako Liber Razielis Angeli w siedmiu księgach, znanego chrześcijańskim kabalistom m.in. w renesansowej Florencji) i pozostawali pod wpływem tradycji arabskich, przede wszystkim hermetycznych, neopitagorejskich i astrologicznych ${ }^{37}$. Sama Sefer Yeșirah została zreszta zredagowana bardzo późno pod islamskim wpływem, najpewniej w VIII lub IX wieku na Bliskim Wschodzie, i należy do dzieł z najwcześniejszego etapu rozwoju nauki żydowskiej przez inspirację i asymilację ze świata arabskiego (zob. np. dyskusję w: Dan 1994, 8 i n.; Wasserstrom 1993, 2002; Tzvi Langermann 2002; Fleischer 2002). Między X a XII wiekiem czytana była w środowiskach żydowskich przede wszystkim jako tekst naukowokosmologiczny, choć jej sens mistyczny i magiczny był obecny jak towarzyszący filozofii przyrody „cień” (zob. Weiss 2013) - podobna ambiwalencja związana z magicznomistycznym podłożem i interpretacjami wczesnych koncepcji naukowych dotyczy też oczywiście samego szesnastowiecznego paracelsyzmu. Pierwsze pokolenie jej czytelników i interpretatorów należało do wspólnego intelektualnego świata arabsko-żydowskiego i wczesna już asymilacja Sefer Yeșirah, zwłaszcza ismailicka z X wieku, dobitnie pokazuje rozległość tej międzywyznaniowej wspólnoty ${ }^{38}$ (zob. np. Wasserstrom 2002, 206 i n.). Z tego samego abbasydzkiego środowiska pochodzi również arabski jej odpowiednik o podobnym tytule, Kitāb Sirr al-khaliqqa (Ksiega tajemnicy stworzenia; Travaglia 2001), hermetycznokosmologiczne dzieło zawierające słynną alchemiczną Tablice sżmaragdowa (Al-lawh alzumurrud), przypisane Apolloniuszowi z Tiany, ale w rzeczywistości powstałe w 1. połowie IX

35 R 143.28-32 / FFU, 78 / FFP, 52. W tym samym fragmencie zostaje złożony hołd „Theophrastowi”, tj. Paracelsusowi, a więc powiązanie późniejszej rewolucji paracelsjańskiej z tą wyprawą „Ojca Fr. R.C.” nie ulega wątpliwości.

36 R 144.5-6: „Ein anderer, deme mit Unrube gedienet, möchte eben wohl reformiren”.

37 Zob. np. Idel (1990, 90 i n.). Późniejszy etap magicznej recepcji Sefer Yeșirah nastapił w kabalistycznym środowisku nadreńskich pietystów (aszkenazyjskich chasydów) w XII-XIII w. i można go w zasadzie uznać za żydowską antycypację późniejszej o cztery wieki chrześcijańskiej recepcji w środowiskach ezoterycznych pietystów luterańskich.

38 Niektórzy żydowscy intelektualiści tej pierwszej fali zainteresowania nauką pod wpływem arabskim, w okresie późnego kalifatu umajjadzkiego i wczesnego abbasydzkiego, pisali po arabsku i tłumaczyli na arabski (jak Masarjawayh z Basry czy Masza’allah), ale inni, jak autor Sefer Yeșirah wybierali język hebrajski, zwracając się początkowo do węższego kręgu odbiorców (Langermann 2002, 175). 
wieku, prawdopodobnie w Bagdadzie (zostało przełożone w Hiszpanii na łacinę przez Hugona z Santalli w XII w. jako De secretis naturae). Ta fuzja tradycji arabskich i żydowskich w dojrzałej postaci jest poświadczona w połowie XIII wieku na przykład u Jehudy ben Nissim ibn Malki ${ }^{39}$; szybko promieniowała ona do arabskiej Hiszpanii, choć trudno precyzyjnie rozstrzygnać, w jakim stopniu wiedzieli o tym autorzy Famy z pierwszych lat wieku XVII ${ }^{40}$. Z kolei kastylijski przekład zbioru Sefer Razi'el został prawdopodobnie przygotowany w trzynastowiecznej Hiszpanii z inicjatywy króla Kastylii Afonsa X Mądrego ${ }^{41}$ i nie zachował się, ale przetrwały do dziś dwa manuskrypty z kompletnym łacińskim tekstem oryginału kompilacji ${ }^{42}$. Odzwierciedlaja one dobrze charakter tych kabalistycznoapokaliptycznych tradycji, które docierały na kontynent, do Hiszpanii i Niemiec: na przykład księga pierwsza (Liber Clavis, Vat. Reg. Lat. 1300, fol. $13 r$ i n.) jest poświęcona astrologii, a kluczowa szósta, która krążyła również osobno w odpisach, Księga niebios (Liber Samayn, fol. 96 i n. $)^{43}$ - ezoterycznej kosmologii, opisowi siedmiu niebios i ich aniołów. Obecnie znanych jest wiele hebrajskichi arabskich manuskryptów źródła Liber Samayn, znanego jako a הפרזים (Ksiegga Tajemnic), którego pionierską hebrajską edycję przygotował w 1966 r. Mordecai Margalioth ${ }^{44}$.

Mówiąc krótko, intensywna osmoza religijno-filozoficzna w świecie arabskim, zarówno bliskowschodnim, jak i północno-afrykańskim, spowodowała, że starożytna wertykalna apokaliptyka żydowska uzyskała nową gwałtowną dynamikę, rozwijając się jednocześnie w kierunku protonaukowym (tj. filozofii przyrody, kosmologii i chemii), a także mistyki przyrody oraz magii - wszystkie one są już implikowane przez tę oś apokaliptyki, nie są w żadnym razie ani wobec niej zewnętrzne, ani nie są do niej zbędnymi dodatkami, ponieważ wiąże je jeden religijny afekt - pragnienie poznania sekretów kosmosu wyrażających się w jego strukturze, które częściowo podlegają pragmatycznej logice użytkowania. Legenda z Famy o niemieckim zakonniku, który szuka w świecie arabskim nowej apokalipsy dla Europy, czyli ujawnienia prawdy „in Theologia, Physica unnd

\footnotetext{
$39 \mathrm{Na}$ temat ibn Malki zob. klasyczną (jedyną monograficzną na jego temat) pracę Georgesa Vajdy (1954).

40 Liber Razielis, podobnie jak Ksiega Henocha i Picatrix, znajduje się - jako najpopularniejszy w Europie żydowski tekst magiczny - w spisie Catalogus continens libros chymicos, Magicos, Medicos, Astrologicos et Cabalisticos..., sporządzonym w 1598 r. własnoręcznie przez Johanna Andrea’ę (zm. 1601), radcę książęcego i prałata w Königsbronn, ojca Johanna Valentina. Młody student w Tybindze z pewnością dysponował wiedzą o tej literaturze magicznej wyniesioną z biblioteki ojca, choć później nie traktował jej poważnie. Zob. Gilly (1995,

41 Zob. Secret (1969) i García Aviles (1997). Teza o alfontyńskiej redakcji księgi opiera się na późnej wzmiance u teologa Johannesa Clericusa, ale niektórzy badacze podaja ją w wątpliwość.

42 Pełna wersja tekstu alfontyńskiego w Bibliotece Watykańskiej: Vat. Reg. lat. 1300, fol. 3-10; nieco skrócona wersja znajduje się w Universitäts- und Landesbibliothek Sachsen-Anhalt w Halle.

43 W niektórych łacińskich odpisach księga jest umieszczana na początku zbioru (Liber primus angeli Razielis), na przykład w najbardziej znanym Cod. Mag. 40 (= Cod. lat. 745) Biblioteki Uniwersyteckiej w Lipsku.

44 Sepher ha-Razim (1966). Zob. też: García Aviles (1997, 27 i n.).
} 52). 
Mathematica" (R 140.4 / FFU, 72 / FFP, 50) wbrew papieżowi i jego wiernemu tłumowi w akademiach, jest zgrabnym literackim ujęciem tego rzeczywistego historycznego splotu. Jest całkiem prawdopodobne, że to właśnie arabska wersja Ksieggi Tajemnic albo Ksiega tajemnicy stworzenia pseudo-Apolloniusza, wraz z Sefer Yeșirah (= Liber Formationis Mundi/de Creatione) „Arabów i Afrykańczyków”, były dla luterańskich ezoterycznych pietystów pierwowzorami Liber M.(ysteriorum), która miała pomóc zniszczyć scholastykę - „błędy artium (quadrivialium)” i ortodoksyjnej teologii, rozpocząć teozoficzną hiper-reformację i stworzyć nową kosmologię (wraz z „Rotae Mundi”, pomocnymi w ustalaniu nadejścia epoki mesjańskiej ${ }^{46}$ ). Nawet opowieść z Famy o odkryciu krypty (Gewölb) ze zwłokami trzymającego sekretny kodeks Chrystiana Rosenkreutza jest kopią opowieści o mumii mędrca w odkrytym grobowcu pod posagiem Hermesa z Sirr al-khaliqa: jest to tradycyjny hermetyczno-apokaliptyczny emblemat ukrytej wiedzy, która jest ujawniana w opozycji do wiedzy publicznej lub uznanej (Eamon 1994, 43). Jako pierwszy zaraz po wydaniu Famy to arabsko-apokaliptyczne zadłużenie piętnował zresztą ortodoksyjnie luterański, antyparacelsjański alchemik i wróg wszelkich kabalistycznych idei Andreas Libavius w swoim Examen philosophiae novae, atakujący różokrzyżowców i ich pochodząca podobno od anioła Raziela zepsutą przez „mahometanizm” Magia Cabalistica, rzekomo używana jego zdaniem do odkrywania wszelkich praw natury i przyśpieszonego przeprowadzania przez człowieka w laboratorium tego, co przyroda realizuje stopniowo $\mathrm{w}_{\text {czasie }}{ }^{47}$. On też już wcześniej protestował przeciwko paracelsjańskiej herezji utożsamiania Fiat-Chrystusa z materia prima i pierwotna natura, rozpoznając w niej „ciężki grzech” zaprzeczenia stworzeniu (Libavius 1610, 76 i n.; zob. Pagel 1961, 120). Intuicja go nie myliła: Bóg paracelsystów to chymik-Separator, a nie Creator, zaś ich sakramentem moga być operacje laboratoryjne naśladujące wulkany albo sady dzięki znajomości uniwersalnego ,alfabetu tworzenia”, lingua formationis.

Inni jednak nie bali się inwazji takiej wiedzy, a wręcz przeciwnie. Arndt, który sam zamierzał uruchamiać rundę tej „,reformacji reformacji” i nowej nauki w luterańskiej Europie, zaraz po ukazaniu się manifestów różokrzyżowych pisał w liście do swojego przyjaciela, pastora z Eisleben i teologa Christopha Hirscha: „Nadchodzi, nadchodzi epoka Eliasza

45 R 142.1-2 / FFU, 76 / FFP, 51: „die Arraber und Africaner”. Niech za dobra ilustrację rzeczywistej symbiozy i hybrydyczności ezoterycznych tradycji w średniowiecznej północnej Afryce posłuży choćby odkryty w Egipcie w latach 70. XX w. chrześcijański arabskojęzyczny manuskrypt Sifr Ādam (Ksiegi Adama), zawierający kompilację trzech ż y d o w s k i c h pism magicznych, m.in. arabską wersję Sefer ha-Razim i tekst Sefer ha-Yashar (Ksiegi Sprawiedliwości) z elementami astrologicznymi, zob. Fodor (2006).

46 Żydowskie, oparte na astrologii arabskiej spekulacje na temat związku między wielkimi koniunkcjami Jowisza i Saturna a nadejściem mesjasza można odnaleźć explicite już u ibn Malki - Idel (1998, 181).

47 Libavius $(1615,25$, sect. V-VI): „In lib. de Sagace Philosophia (...) Magiae speciem (...) vocat (Paracelsus przyp. M.W.) (...) Cabalisticam, qua in mense fiat id quod natura anno integro perficit, \& qua possit cognosci id quod ultra mare est, \& longe dissitis in locis. (...) Et in fama fraternitatis specimen est Magiae talis, quo absentia cognoscuntur, ¿ arcana". Zob. także: Libavius (1616, 116, 120 i n.). Również u Libaviusa widoczna jest obawa o „czystość” wiedzy Arabów. 
Artysty, tak jak zapowiedział Król Filozofów i Lekarzy (tj. Paracelsus - przyp. M.W.). Wattpię, czy sam będę jeszcze przy życiu, gdy się to stanie. Winszuję nadchodzącej epoce tak wielkiego światła..." ${ }^{48}$. Owa „epoka światła”" ${ }^{49}$, nowoczesność paracelsystów i teoalchemików, zaczęła się więc jako naukowa phantasia clamosa: od „nowych okazów z Afryki”, apokalupsis kombinatorycznego jezzyka przyrody i warsztatów doświadczalnej chymii („Spagyrische Philosophie”) eksplorującej materię oraz „przeprowadzającej w miesiąc to, czego przyroda dokonuje w cały rok". Cała Europa, ignorując rzymskich katolików i scholastycznych sofistów, ma zrobić to, co zrobiono jedynie wstępnie, dostając się do ukrytej krypty: wyjść szybko ku nowej epoce, to znaczy zburzyć mur i otworzyć drzwi, „które już daja się widzieć” (R 152.13-17 / FFU, 88 / FFP, 57). Realizująca się w laboratorium przyrodniczo-religijna apokalipsa staje się teraz sojuszniczką i taranem młodej nowoczesności.

Można traktować z rezerwą tę historyczną fazę jako ekscentryczne marzenie wczesnego protestanckiego paraoświecenia, albo też poważniej, jak na to chyba zasługuje: od wielkiego naturalisty Jana Jonstona z Leszna (który znał Andreae’ę osobiście i któremu zawdzięczał fascynację przyrodoznawstwem) ${ }^{50}$ wiedzie droga do Linneusza i Buffona, od Sędziwoja, Eglina i Figulusa do Glaubera, Boyle’a i alchemicznych prac Newtona, od panzofii Komeńskiego i Hartliba do Royal Society i francuskich encyklopedystów ${ }^{51}$. Oczywiste, że

48 Oryginalny laciński fragment z niepublikowanego listu z ok. 1617 r. cyt. w: Gilly (1997, 65): „, Veniet, veniet seculum Heliae Artistae a Monarcha Philosophorum Medicorumque praedictum. (...) Gratulor futuro seculo de tanta luce". Jak na ironię, w niektórych kręgach spirytualistyczno-weigeliańskich sam Arndt był prawdopodobnie uważany za Eliasza Artystę i trzeciego - po Husie i Lutrze - reformatora chrześcijaństwa (Wollgast 1993, 521).

${ }^{49}$ Fama na przykład, bolejąc nad głębokim kryzysem swoich czasów, zapowiada epokę oświecenia i widzi już jej brzask: „... wiemy, że po pewnym czasie nadejdzie powszechna Reformacja divina et bumana, zgodnie z naszym pragnieniem i oczekiwaniem innych. Albowiem jest rzeczą stosowną, by zanim słońce wzejdzie, rzuciło ono na niebo jasne lub ciemne światło” (R 158.1-7 / FFU, 96 / FFP, 59).

50 Foucault $(2000,174$ i n.) słusznie sytuuje Jonstona jako kluczowa postać rozwoju gatunku historii naturalnej w opozycji do kartezjanizmu i bez związku z filozoficznym racjonalizmem, ale przemilcza paracelsjańskie i apokaliptyczne, zwłaszcza Baconowskie zaplecze jego myśli. W O stałości natury Jonston (1634) zwrócił się przeciwko zdziczałemu religijnemu millenaryzmowi, broniąc eschatologicznego optymizmu wiedzy i praktyki, typowego wcześniej dla alchemoparacelsyzmu (zob. część pierwsza). Foucault pisze: „... [W epoce klasycznej w historii] chodzi o to, aby po raz pierwszy objąć dociekliwym spojrzeniem same rzeczy, a następnie zapisać to, co zostało ujrzane, w bezbarwnych, neutralnych i wiernych słowach. Jasne jest, że przy tej 'puryfikacji' pierwszą formą historii, jaka powstała, musiała być historia natury" (tamże, 177). Przykład Jonstona jest bardzo interesujący właśnie jako ilustracja puryfikacji działającej w obrębie samej formacji apokaliptyki, całkiem niezależnie od triumfu mechaniki, co sprawia, że wytwory przyrody jako wielowymiarowe obiekty ze swoją anatomia, fizjologią czy zmiennością stały się fascynujące same w sobie, w ich „nagości”. Nie zgadzam się jednak z Foucaultem, że powstanie właśnie historii natury w XVII w., a nie (ludzkiej) „historii powszechnej”, jest oczywiste, skoro wiek XVI obfitował przecież w millenarystyczne kronikochronologie - raczej jest to kolejny argument za tym, że właśnie poreformacyjna apokaliptyka przyrodnicza i jej ewolucja była rzeczywiście kluczowa dla wczesnej nowoczesności. Zachodząca na jej polu puryfikacja polega na tym, że słowa oddzielają się od „nagich rzeczy”, idea linguae formationis traci siłę nośną i paracelsjańska ontologia wyrażania przestaje w końcu efektywnie funkcjonować, co od 2. polowy XVII w. wymuszało na mentalności apokaliptycznej głęokie rewizje, na przykład nieudane sięganie do platonizmu i rozdęcie czysto religijnego symbolizmu jako typowy wehikuł konserwatywnych zwrotów.

51 Zob. np. Webster (2002; 1992, 62 i n.). Fundamentalna krytyka historiograficznych konstrukcji opartych na procedurach oszyszczania i genealogicznego oddzielania archaicznych „,nauk tajemnych” od „nowożytnej 
znajomość konstrukcji i logiki kosmosu, a także jego „alfabetu”, uniwersalnych elementów konstrukcyjnych, otwiera możliwość modyfikacji rzeczywistości zgodnie z wola („magia” jako „dziedzina/ars doświadczalna” ${ }^{52}$ ) oraz planowego przekształcania substancji (transmutatio metallorum i chymiczna farmacja), zatem dylemat chrześcijańskich stronników Eliasza nauk, pobożnych uczniów „Rosenkreutza”, to dylemat wczesnonowożytnego apokaliptyka: jak wykorzystać w praktyce wiedzę o sekretach przyrody, jej materii i siłach (kryjących się w domniemaniu za dziwacznymi imionami aniołów i permutacjami elementów-,,liter”)? Fama zabrania wykorzystywania jej do nadużywania władzy (ma być stosowana do leczenia, poprawiania losu ludzkości), jest też wrogo nastawiona wobec wulgarnej alchemii balansującej na krawędzi oszustwa czy jej karykatury jako Goldmacherkunst (nawet Paracelsus uważał przemianę metali za niemożliwą przed rozpoczęciem na dobre epoki Eliasza nauk, zob. Telle 1994, 157-172; Gilly 1997, 63). Kończy się więc ona, w zgodzie z tradycją Sefer ha-Razim, manifestem apokaliptycznej mistyki przyrody:

\section{(...) ten, d la k o go o tw arta je st c ał a natu ra (welchem die gantze Natur offen), nie cieszy się tym, że może robić (złoto), czy też, jak powiada Chrystus, że posłuszne są mu diabły, lecz że widzi o twa rte niebo, A niołów Bo żych w stępujących i zstępujacych (er siehet den Himmel offen und die Engel Gottes auff und absteigen), i że jego imię zapisano w Księdze Życia ${ }^{53}$.}

Tajemnice przyrody, które mają być odkrywane, nie dotyczą już tylko organizacji sfer niebieskich, geografii ani położenia „zbiorników śniegu i gradu” (Job 38, 22), lecz „wnętrzności przyrody” (Andreae): ukrytych fizycznych potencji, immanentnych sił

nauki”: Hanegraaff (2012, rozdz. 3) i Moran (2006); zob. też: Copenhaver (1990), oraz von Greyerz (1999, 415-432). Trzydzieści lat temu Herbert Breger $(1984,49)$ słusznie ubolewał nad całkowitym ignorowaniem roli utopijnego mitu Eliasza Artysty przez historyków wczesnej nauki.

52 Przykład takiej redefinicji i rewaloryzacji renesansowej idei magii (pochodzącej w dojrzałym kształcie przede wszystkim od Pico della Mirandoli) w pietystycznym kontekście można znaleźć u Andreae’i, gdy pisze, że „magia to nieustające studium wielu nauk” (,Magia est multarum artium studium, illudque assiduum”) - Andreae (1616, 79, nr 557; 2003, 194-5). Podobnie magię jako „praktykowane poznanie” przyrody ujmuje w Ikonografii też Arndt (1596, fol. 16v): „... Magia / eine gründtliche Erkentnus ist aller Thiere / Gewechse / und der Sternen...”. Jest to w ogóle motyw paracelsjański - porenesansowy impuls odwagi i dociekliwości działający na polu philosophia practica, zwłaszcza w chemii i medycynie, tak by znaleźć zupełnie nowy fundament „aus der philosophei, astronomei, und alchimei" (Paracelsus 1924a, 37 i 41). Zgodnie z opinią Paracelsusa samą chymię i magię należy rozumieć bardzo szeroko jako każde celowe przekształcanie substancji (zob. np. Prinke 2014, 310), które daje człowiekowi nieograniczone w zasadzie możliwości zarówno laboratoryjnej syntezy wszystkich substancji występujących w przyrodzie, jak i wytwarzania nowych. Jakościowo zajmują się one tym samym co przeprowadza nieustannie sama przyroda - na przykład ludzki żołądek i jelita to dla Paracelsusa alchemiczne laboratorium (zob. Wollgast 1993, 652). Na temat roli magii naturalnej w porenesansowym rozwoju praktyk eksperymentalnych i osłabianiu tradycji arystotelesowskiej przez pragmatyczne zainteresowanie „ukrytymi jakościami/przyczynami” (qualitates occultae/causae abditae) i potraktowanie zjawisk „cudownych” jako w pelni naturalnych zob. np. Henry (2008) i Hanegraaff (2012, 178 i n.). Na temat analogicznej wiedzotwórczej roli praktyk alchemicznych w XVI i XVII w. zob. np. Moran (2006).

${ }^{53}$ R 160.10-15 / FFU, 98 i n. / FFP, 61; podkr. - M.W. 
(„archeuszy” i „wulkanów”) natury i niekończących się, subtelnych przemian materii, przypominających niewyczerpywalne życie, którego źródła nie są bezpośrednio dostrzegalne zmysłowo. Dlatego emblemat XLII z różokrzyżowej Atalanta fugiens (1618) lekarza Michaela Maiera, arcydzieła alegorycznej literatury barokowej, przedstawia chymika w okularach, z laską i latarnią, idącego głęboką nocą po śladach Natury, stylizowanej na Florę w zwiewnych szatach, niosąca kwiaty i owoce, a komentarz Maiera brzmi: „Niech Natura będzie twoja przewodniczką i towarzyszką w tej wielkiej podróży - idź jej śladami”" ${ }^{54}$. Ta Natura-Bogini, prowokująca chymika do podróży w środku nocy (niewiedzy) i realizacji „celów naturalnych”, subjecta naturalia, wyraźnie zas tęp uje już a nioła starożytnych a pokalips, który unosił wizjonera w niebiosa i ukazywał mu „sprawy boskie”. Poznanie dynamiki kipiącej ukrytym życiem materii ma być prowadzone intimè, „do głębi” - rzecz trudno wyobrażalna w świecie scholastyki z jej płaskim pojęciem materii, które nie groziło fascynacją nią ani „herezja” materializmu. Ta chrześcijańska religia przyrody jest w całości wytworem formacji paracelsjańskiej, ale - jak już podkreślałem - nie kontynuacją, lecz wyraźnie nowoczesna metamorfozą starożytnej apokaliptyki, która wyróżnia teraz laboratorium chymiczne z jego substancjami i procesami jako szczególny obszar aktywności, fascynacji, a nawet mistycznego afektu, ściśle wiążącego zagadkę materii z twórczością, przemianą i zbawieniem. Wczesnonowożytne laboratorium jest przestrzenia aktywnego ujawniania ukrytej strony przyrody, „Naturae examen” (Andreae 1619,41), które dopełnia tradycyjną rolę obserwatorium astronomicznego, jak w jednym $\mathrm{z}$ pierwszych znanych szczegółowych projektów z Uranienborga na wyspie Hven, w którym Tycho de Brahe pracował w latach 1576-1597 i który również gwałtownej krytyce poddał Libavius ${ }^{55}$. Późniejszym o dwieście lat dopełnieniem tej wizji jest hipernowoczesna, postspinozjańska mistyka Fausta Goethego, zanurzonego od młodości w paracelsjańsko-pietystycznej duchowości wyznawcy religii

\footnotetext{
54 Maier (1618, 178, Disc. XLII): „Prima itaque intentio est, naturam intimè contemplari quomodo procedat in suis operationibus eo fine, ut subjecta Chymiae naturalia absque defectu aut superfluitate baberi queant: Unde natura fit dux \& comes tanti itineris, cujus vestigia sequenta sunt”' („Pierwszym więc zadaniem niech będzie dogłębna kontemplacja przyrody, tego, jak przebiegają jej działania, po to, by osiagnąć naturalne cele Chymii, bez niedostatku ani nadmiaru. Niech Natura będzie twoją przewodniczką i towarzyszką w tej wielkiej podróży, idź jej śladami’). Okulary są symbolem doświadczenia, laska - rozumu, a latarnia - wiedzy pochodzącej z wcześniejszych studiów.

55 W swoim ważnym eseju Owen Hannaway (1986) argumentował, że projekt laboratorium Libaviusa z 1606 r. odzwierciedla wczesnonaukowe odrzucenie paracelsjańskiego, arystokratycznego etosu „tajemnych badań” na rzecz humanistycznego, mieszczańskiego ideału wiedzy otwartej i użytkowanej społecznie, ale trafnej krytyce poddał tę tezę Shackelford (1993), zob. Prinke (2014, 361 i n.). Laboratorium w piwnicy Uranienborga nie było bynajmniej ani miejscem kontemplacji, ani żadnym sekretem (Shackelford 1993, 226 i n.). Tym niemniej kampanię Libaviusa (motywowaną też przez jego antykalwinizm graniczący $z$ teorią spiskowa) i jego wyobrażenia na temat modelowego „domu chemii” rzeczywiście można interpretować jako interesujący przejaw zachodzącego już podziału pracy między religię a naukę i technikę, jak w projekcie Andreae’i (1619, 41 i n.). Ale nawet laboratorium Libaviusa jest hybrydą (Newman 1999). Z szerszej perspektywy dyskusji nad rola apokaliptyki, istotną kwestia jest jednak nie obecność jakichkolwiek ezoterycznych (nie wspominając paracelsjańskich) elementów, która istotnie stawała się marginalna, lecz raczej religijny konglomerat motywacji do badań i mistyczny nimb wokół coraz skuteczniejszego odkrywania „tajemnic Natury”.
} 
przyrody: od doświadczenia przez Fausta immanencji twórczej potęgi Ducha Przyrody, „szyjącego żywioły” w kosmicznej „przędzalni czasu”56, po magiczne wytworzenie sztucznego człowieka, Homunkulusa, zgodnie z paracelsjańskim marzeniem z traktatu De natura rerum, opublikowanego w 1572 r. (Paracelsus 1928b, 313 i n.) ${ }^{57}$. Nowożytna apokaliptyka jest immanentystyczną religia odkrywania sekretów przyrody, fascynacji jej głębia oraz twórczymi siłami. Dla paracelsjańskiego mistyka otwarta przyroda to otwarte niebo - sama mistyka staje się tu powoli tym samym co magia naturalna i apokalupsis początku jednocześnie.

Ma to konsekwencje głęboko niepokojące z perspektywy chrześcijańskiej ortodoksji, ale na tym zupełnie nowym napięciu, którego nie znało katolickie średniowiecze, buduje swój afektywny impet młody religijny nurt nowoczesności. Kierunek, w którym podąża, dobrze ilustruje różokrzyżowy miedzioryt wykonany, gdy Boehme kończył właśnie swoje Mysterium Magnum: Tabula Universalis Abrahama von Franckenberga z Bystrego pod Oleśnica, ucznia i biografa Boehmego ${ }^{58}$. W samym centrum Tablicy znajduje się postać, którą ze względu na atrybuty: siedem gwiazd, księgę $z$ alfą, omega i siedmioma pieczęciami oraz miecz w ustach, zwykle interpretowano za W.-E. Peuckertem po prostu jako Chrystusa (Ap 1, 13-16), lecz Carlos Gilly (2002, 231 i n.) słusznie zwrócił uwagę, że w istocie jest to niewłaściwe, co zreszta jako pierwszy z pogarda punktował Libavius, jako alchemiczny hiperkonserwatysta krytykujący wszystkie ambiwalencje tekstu Famy ${ }^{59}$. Krąg opisany jest jako „Theousia” (Przebóstwienie) poprzedzona przez „Theoria” (Ogląd/Kontemplacja) i oprócz loci z Ap 1, 13 i 19, 11-16, wskazane są wokoło trzy cytaty ze św. Pawła: 2 Kor 3, 18; Flp 3, 20-21 oraz Rz 8, 29. Ludzie przyszłości, „z odsłoniętym obliczem, oglądając jak w zwierciadle chwałę

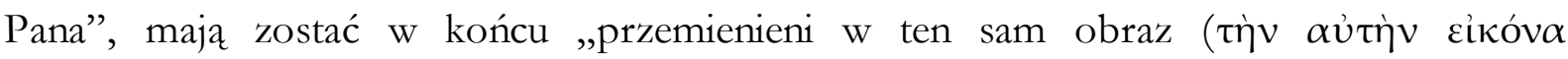
$\left.\mu \varepsilon \tau \alpha \mu о \varrho \varphi u^{\prime} \mu \varepsilon \theta \alpha\right)$, z chwały w chwałę", w podobiznę Chrystusa. Ujawnienie sekretów wszechświata jest jak ponowne związanie początku i końca - panowanie poprzez „słowo” (płomienny miecz wychodzący z ust) nad materią i historią-czasem, człowiek będzie bowiem u kresu jak Chrystus, Centrum Mundi. Jest to ten sam sposób myślenia, co w cytowanym wcześniej fragmencie WCh IV, 1,30-31 Arndta. Jeszcze radykalniejszą, całkowicie antykalwińską formę przyjmuje on u Bacona, u którego zgodnie z planem Boga ostatnia

\footnotetext{
56 Johann W. Goethe, Faust, cz. I, w. 501-509. Zob. Woszczek (2007, 169).

$57 \mathrm{Na}$ temat przejęcia motywu przez Goethego zob. klasyczny artykuł Edmunda O. von Lippmanna (1920).

${ }^{58}$ Franckenberg studiował w Jenie i Lipsku w momencie, gdy ukazywały się manifesty różokrzyżowe, które wywarły na niego istotny wpływ (jak równolegle w przypadku Michaela Maiera i wielu innych), zanim jeszcze poznał samego Boehmego w 1623 r. Miedzioryt Tabula Universalis, której cała symbolika odwołuje się do Famy Fraternitatis, podarował swojemu przyjacielowi Johannowi Danielowi von Coschwitz w Laskowicach koło Brzegu w święto Trzech Króli 1623 r. Coschwitz był centralną postacią kręgu uczniów Boehmego w Strzegomiu.

${ }^{59}$ Libavius $(1616,94)$ : „Das Centrum solcher Sphaer sol der Mensch sey in welchem die ganze Welt verfasset gehalten wirdt. Crollius nennet auch Gott das Centrum"; oraz Libavius (1616, 107 i 124).
} 
epoka to Regnum Hominis, Królestwo Człowieka - „panowanie rodzaju ludzkiego we wszechświecie" (Bacon 1955, 159) na drodze odwrócenia upadku za pomocą nowych nauk. Bacon rozumiał to również, podobnie jak Gutman, jako odbudowę świątyni Salomona obrazu kosmosu (Bacon 1955 147), czyli, zgodnie z tradycją bazująca na J 2,21 i 1 Kor 3,16, przemienienie ludzkiego rozumu (intellectus) w „ciało Chrystusa”! Epokę „Theoria” u mistycznych paracelsystów zwiastuje „trzeci Eliasz”, który jest jej symbolem i przewodnikiem, jest to więc epoka ludzi dążących przez poznanie i działanie do przebóstwienia - chymiczna religia przyrody to rzeczywiście nowa apokalipsa. Centrum miedziorytu Franckenberga jest więc kolejną wczesnonowożytną religijną hybryda, wyprodukowana przez paracelsjańską formację - jak przywołana wcześniej chymiczna góraGolgota ze Speculum Sophicum Rhodo-Stauroticum.

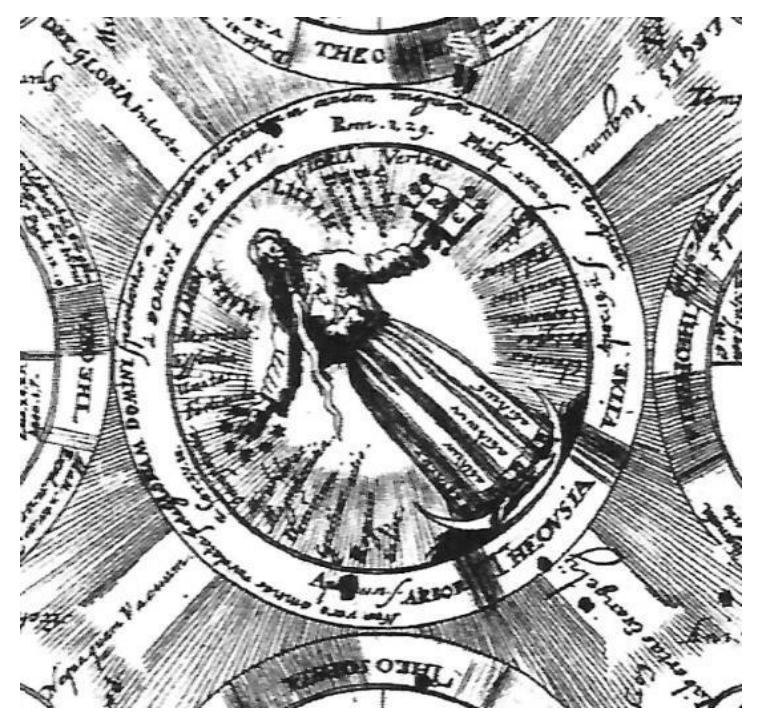

Przebóstwiony człowiek przyszłości (Eliasz nauk/Chrystian Rosenkreutz/, homo purissimus”

Dorna jako archetyp?) w centrum miedziorytu Tabula Universalis Theosophica Mystica et Cabalistica Christianismi Catholici Abrahama von Franckenberga (1623)

Można przekonać się, jak głęboka zmiana w stosunku człowieka do przyrody musiała wówczas zachodzić, czytając na przykład u Figulusa, że dokonujący w laboratorium operacji na materii chymik czasowo przeprowadza na metalach to, co Chrystus zrobił wcześniej „swoją Tynkturą” dla upadłych ludzkich dusz: „das Werck ist Göttlich”" ${ }^{\circ 0}$ To samo śladem Khunratha sugerował w tym czasie Eglin, zaprzyjaźniony z Figulusem wykładowca teologii w Marburgu, we wspomnianej antyjezuickiej Disquisitio de Helia Artium (1606, 1608), a

${ }^{60}$ Figulus (1608b, 46): „Unsere TINCTUR tingiert allein zeitlich die Corpora, das sie unbemackelt gesund erhalten werden und gibt den unvollkommenen Metallen Solis vel Lunae glant\%. CHRISTI TINCTUR Aber tingiert Geistlich an der Seelen zum ewigen Leben". 
potem też pozostający z nim w kontakcie Michael Maier i wielu innych teoalchemików, nie wspominając już nawet samego Boehmego. Eglin odwołuje się, oczywiście za Paracelsem, do słów Jezusa z Łk 12, 2: „Bo nie ma nic ukrytego, co nie będzie ujawnione” ${ }^{61}$, i wskazuje rok 1600, swoje czasy, jako otwarcie rewolucji (Hapelius 1612, 138 i n.) - rewolucji korzystania z sił natury i dokonywania przemian przez experimentatores, mistrzów fizyki i chymii, a nie magii i cudów, takich jak te demonstrowane przez starożytnych kapłanów i Mojżesza ${ }^{62}$. Paracelsus nie posuwał się może tak daleko jak później jego uczniowie-teoalchemicy, ale też nie miał watpliwości, że samo tylko lumen naturae, nie mówiąc już o magia coelestis, pozwala ludziom samodzielnie wznieść się ze stanu poznawczego upadku („labiryntu świata” ${ }^{63}$ ) na niebywałe wyżyny wiedzy, nawet jeśli nauka będzie kiedyś potrzebować swojego Eliasza, by rozwiązać mogła najtrudniejsze zagadki. Właśnie to nastawienie, tak jaskrawo odmienne od nastawienia katolickiej mistyki monastycznej, charakteryzuje paracelsjańską mistykę przyrody, co pokazuje, w jakim stopniu prezentowanie jej jako „wciąż średniowiecznej” jest nieporozumieniem. W De imaginibus Paracelsus, po tym, jak fantazyjnie spekuluje na temat tworzenia sztucznych ludzi, homunkulusów, stwierdza krótko, przywołując jako przykłady Eliasza i Henocha: „I gdybyśmy my, ludzie, dobrze zrozumieli naszą duszę (gemüt), nic nie byłoby niemożliwe dla nas na tej ziemi” (Paracelsus 1931, 383). Jest to hermeneutyczna mutacja wczesnej nowoczesności, wynik przesunięcia osi i pól działania: zmiana i reinterpretacja zdania z zakończenia Panstwa Bożego św. Augustyna, które Bloch (1985b) uczynił zresztą mottem swojego Ateiżmu w chræeśsijansstwie: „My sami będziemy dniem siódmym” ${ }^{64}$ (zob. w kontekście paracelsyzmu: Bloch 1985c, 223).

\section{Empiryści przeciw jezuitom. Wczesna nowoczesność jako religijna mutacja i polityczny kryzys}

Ta inflacja mistyczno-immanentystycznej wiary w człowieka i aktywne poznanie oraz działanie jako „naśladownictwo Chrystusa” wraz z dynamiczną wizją przyrody rzeczywiście

\footnotetext{
${ }^{61}$ Hapelius (1612, 135): „Nibil est absconditum, quod non sit retegendum”; także: Philochemicus (1608, 19 i n.).

${ }^{62}$ Hapelius (1612, 206 i n.): prawdziwa sztuka alchemiczna, vera ars chymiae, nie potrzebuje żadnych cudów ani sił nadprzyrodzonych, lecz tylko sił i materii przyrody, „quod natura generavit ac generat, adbibita mixtione \& debita praeparatione", ponieważ to sama przyroda n i e u s t a n n i e przeprowadza przemiany substancji (Hapelius 1612, 113). Dokonuje się tutaj - w odróżnieniu od aksjologii średniowiecza - czysto teologiczna rewaloryzacja eksperymentalnej manipulacji materią.

63 Metafora świata-labiryntu jako konsekwencji ubezwłasnowolnienia umysłu przez tradycję i niedorozwoju umiejętności niezależnego „czytania przyrody” np. w: Paracelsus (1928a, 170).

64 Oryginalne, ortodoksyjne sformułowanie św. Augustyna (De Civitate Dei, 22, XXX,4) brzmiało: „dies enim septimus etiam nos ipsi erimus, quando eius fuerimus benedictione et sanctificatione pleni atque refecti” („Wszak r ó w n i e ż i m y sami będziemy tym siódmym dniem, kiedy przez jego (tj. Boga - przyp. M.W.) b ło g o s ła w i e ń s t w o i u ś wi ę c e ni e osiągniemy swą pełność i odnowę" - tłum. i podkr. M.W.) - św. Augustyn $(1977,616)$.
} 
sa, jak chciał Blumenberg, skutecznym przezwyciężeniem opartej na poczuciu winy i „chorobie skrupułu” (Delumeau 1994, 5 i n.) średniowiecznej antropologii oraz przygnębiająco statycznej, monarchicznej kosmologii - przezwyciężeniem zupełnie niedialektycznym (nie żadną inwersją ani antyteza), to znaczy autonomiczna formacją wynikająca z nowego układu społecznych sił, działań i form podmiotowości, które ja zasilają. Obserwujemy tu przebiegające szybko mutację i hybrydyzację, nieprzewidywalne wyłonienie się samodzielnego kulturowo-materialnego układu odniesienia, a nie pracująca „dialektykę sekularyzacji” ani żadną domniemaną „nowoczesną impietas”. Symptomem tej mutacji jest na przykład fakt, że w dużej mierze neutralna ideologicznie do czasów Lutra alchemia i filozofia przyrody stała się obszarem studiów protestanckich intelektualistów i lekarzy drugiej i trzeciej generacji, i nagle, od połowy XVI w., polem gwałtownej walki o reżim prawdy, a więc i nośnikiem kluczowych afektów i przemieszczeń relacji władzy (Trepp 1999, 485 i n.). Przednowoczesny skrupuł zaczął ustępować nie dlatego, że nagle padł ofiarą jakiejś nieuprawnionej hubris i wypaczenia, generujących domniemane sprzeczności (w rodzaju „mistyki przyrody”, „chemicznej chrystologii” albo „magii laboratoryjnej”) albo niekonsekwencje (jak „religijna nowoczesność”), lecz dlatego, że nowe społeczne praktyki i zainteresowania uruchomiły nieodwracalnie przesunięty i „ugięty” układ odniesienia, co sprawiało, że wcześniejsze pojęcia i cele nie znaczyły odtąd i nie mogły znaczyć tego samego. Na przykład nowy rodzaj przyrodniczej apokaliptyki zarazem i redefiniuje religijną eschatologię, i napędza jako motywacja kolejne eksperymentalne praktyki. Jak widzieliśmy, wygenerowała ona także spontanicznie nowy typ mistyki odpowiadający rekonfiguracji praktyk i związanych z nimi obrazów przyrody, to znaczy immanentystyczny model religijnego doświadczania przyrody, opozycyjny wobec dualistycznego kartezjanizmu ante litem motam. Tej immanentyzacji nie należy jednak rozumieć historiozoficznie jako jakiegoś „dziejowego zwrotu”, co bezkrytycznie reprodukuje wyobraźnię millenarystyczną na metapoziomie analizy i niczego nie wyjaśnia, ale jako rozproszony społeczny efekt sprzęgania wielu heterogenicznych czynników: od masowego druku konfesyjnych treści i zindywidualizowanego kaznodziejstwa, przez popularyzację zmodyfikowanych metafor przyrody, po projektowanie nowej przestrzeni jako „laboratorium” i eksperymentowanie ze składem leczniczych maści. Jak podkreślałem w części pierwszej, w przypadku alchemoparacelsjańskiego mitu jego otwarcie chiliastyczne komponenty stosunkowo szybko zaczęły słabnąć i ulegać przekształceniom, w przeciwieństwie do zasilającej go szerokiej formacji wertykalnej apokaliptyki, która - wbrew temu, co sądził Blumenberg - działała nadal, sterując przez cały XVII wiek rozmaitymi praktykami naukowymi sondującymi ,żywą księgę przyrody”. Jednym z najbardziej zaskakujacych tego efektów były rewolucyjne zmiany w rozumieniu sensu gromadzenia wiedzy o przyrodzie, powszechnej „pedagogiki uniwersalnej” i pisania podręczników 
przyrodoznawstwa, czego pionierami byli w Lesznie Komeński i Jonston, obaj zainspi rowani programem Andreae'i ${ }^{65}$.

Nowoczesna apokaliptyczna mutacja motywacyjnej metafory liber naturae nie miała wiele wspólnego z jej średniowiecznymi, ortodoksyjnymi wersjami, od św. Augustyna po Bonawenturę: właściwa tym ostatnim rola pobożnościowo-formacyjna i teologicznoapologetyczna, kształtująca religijny afekt w formę sztywnej uległości wobec politycznego ordo creationis i Kościoła, jest marginalna albo bez znaczenia, zaś na pierwszy plan wysuwają się funkcje poznawczo-eksploracyjna, wytwórcza i edukacyjna, nakierowujące ten afekt na niezależne p o znaw a ni e dynamiki („arkanów”) przyrody i w efekcie stopniowo niszczące relacje władzy ukształtowane na horyzontalnej osi eschatologii oraz jej politycznej logiki ${ }^{66}$. Alchemoparacelsyzm i mistyka przyrody były więc po renesansowej filozofii przyrody lokalnym medium tej immanentystycznej (wertykalnej) reorientacji, która rozpoczęła się przed wojna trzydziestoletnią i trwała później jako twórczy kryzys - stan normalny nowoczesności ${ }^{67}-\mathrm{w}$ samym centrum świata protestanckiego. Zarówno niesmaczne snucie opowieści w konserwatywnej manierze o linearnych, nieszczęśliwych losach eschatologii i transcendencji, jak czynili to Löwith (,irreligia postępu”) czy Voegelin, a także cała rzesza konserwatywnych epigonów-moralistów tęskniących za średniowiecznym ordo (w rodzaju C.S. Lewisa) albo uznaniem polityczno-metafizycznejk onieczności nadnaturalnej transcendencji „prawa Bożego” (R. Brague), jak i też preparowanie źródłowo funkcjonalnej, antyreligijnej racjonalności idei postępu i nauki (Blumenberg), ignoruja bogactwo tej kulturowo-społecznej mutacji, wymazując całe jej hybrydowo-religijne segmenty, nie odróżniaja pierwotnej osi spekulatywno-kosmologicznej apokaliptyki od horyzontalnego, płaskiego millenaryzmu (średniowiecznego w szczególności, branego za modelowy), myląc ich odmienne dynamiki i semantyki ${ }^{68}$, i wreszcie pracują na zredukowanych albo wręcz

65 Niezastapione studium takiego zredefiniowanego przez apokaliptykę przyrodniczą, antyautorytarnego i oświeceniowego millenaryzmu (wraz z rolą Komeńskiego) w purytańskiej Anglii XVII wieku to Webster (2002).

66 Por. np. Moran (2006, 187 i n.). Głębokość tego przesunięcia można sobie uświadomić, gdy porówna się perspektywę szesnastowiecznych paracelsystów i ich lumen naturae z przednowoczesnym, katolickim rozumieniem liber naturae u Bonawentury, odnoszącego się z wrogością do arabskiej i żydowskiej filozofii przyrody. Wykładając w Paryżu na krótko przed słynnymi potępieniami z 1277 r, głosił w Collationes in Hexaëmeron (II, 7): „Najwyższą obrzydliwością jest, gdy najpiękniejsza córa króla jest nam zaofiarowana jako małżonka, a my wolimy uprawiać nierząd (copular) z najpodlejszą służącą i iść do prostytutki" (Bonawentura 1891, 337). Małżonką jest mądrość (sapientia) chrześcijańskiej teologii, służącą i prostytutką - nauka i filozofia przyrody pogan; przyroda to księga do kontemplacji wielkości Boga, studia filozofii przyrody bez korygującego „światła prawd wiary” to prostytucja. Do podobnej retoryki zbliża się też później Luter, co zresztą pokazuje przepaść między nim a paracelsjańską mistyką i apokaliptyką przyrodniczą.

67 Podobnie widzą to Michael Hardt i Antonio Negri (2005, 90 i n.).

68 Nieusuwalne napięcie między wertykalną apokaliptyką (genetyczną bazą żydowskiej i chrześcijańskiej mistyki) a horyzontalnym millenaryzmem istnieje w tradycji judeochrześcijańskiej od starożytności i nie jest żadna jej deformacja. zob. np. wspaniałe studium Rowlanda (1982, cz. IV i V, 269-441). „Wiedza o tym, co już istnieje może łatwo dostarczać samoistnej satysfakcji kosztem ziemskiego spełnienia w przyszłości. Apokaliptyka zawiera w sobie ziarna zniszczenia historycznej eschatologii” (Rowland 1982, 445). Próba 
karykaturalnych obrazach nowoczesności XVI i XVII wieku. Z drugiej strony, nigdy nie istniał też żaden spójny ,judeochrześcijański mesjanizm”, który mógłby służyć za podstawę globalnej tezy o sekularyzacji ${ }^{69}$ - było ich wiele i zawierały, jak zreszta cała apokaliptyka, rozmaite sprzeczne tendencje manifestujące się społecznie na skrajnie odmienne sposoby.

Kwestia początku nie ma, co oczywiste, tylko sensu teologiczno-kosmologicznego, ale i o wiele bardziej prozaiczny - historyczno-genealogiczny: od razu wyraźniej ujawnia domenę polityki wiedzy. Impuls instauracyjny nowych nauk i nowej kosmologii jako mit założycielski Famy Fraternitatis jest na przykład ulokowany w odległym Oriencie, świecie arabskim, a nie w bezpiecznym mateczniku chrześcijańskiej Europy, który traktowany jest bardzo krytycznie jako naukowo zacofany i fanatyczny: autorzy gardzą ciemnotą Kościoła katolickiego, wyśmiewaja „ośli ryk papieża” zdeptanego w Europie przez reformację, ale wśród kandydatów do „wytargania za kudły” i kopniaka sa nie tylko papież w Rzymie i Mahomet, ale i teologowie oraz akademiccy sofiści jako arystotelesowscy sztukmistrze ${ }^{70}$. Co zdumiewające, młody „Chrystian Rosenkreutz” wyrusza jako pielgrzym do Ziemi Świętej, ale gdy już dociera do Damaszku, rezygnuje z odwiedzin Grobu Pańskiego w Jerozolimie (do której nigdy nie trafia), „zawiera układ z mistrzem Arabów” ${ }^{71}$ i wybiera pobieranie nauk $\mathrm{u}$ arabskich uczonych, co jest nie do pomyślenia w przypadku chrześcijańskich opowieści o pielgrzymach. Cała tradycja wynaleziona paracelsjańskiej formacji kontynuuje waleczna trajektorię wczesnej nowoczesności w jej renesansowym zrywie jako odrzucenie via antiqua, scholastyki i katolickiej teologii, ale czyni to sięgając do głębszych i bardziej egzotycznych rezerw symbolicznych niż znajomy już Platon, Cyceron czy Epikur, którzy często również sa odrzucani. Robi przy tym użytek z biblijnej genealogii, samodzielnie interpretując ją na swój własny sposób i rewaloryzując modus operandi zmierzający do odkrycia najgłębszych sekretów

celowego usunięcia tego napięcia jest typową taktyką oczyszczania, by historię tej tradycji ex post uniesprzecznić, zlinearyzować i przedstawić jako monolit (Löwith) albo skrajnie ideologicznie skonstruować jako historię upadku (Voegelin zafiksowany na postaci Joachima di Fiore oraz podstawiający swoje karykaturalne i dyletanckie pojęcie „gnozy” w miejsce całej wymazanej wertykalnej osi apokaliptyki). Z kolei pominięcie specyficznej dynamiki tej kosmologicznej apokaliptyki w relacji do wczesnych dyskursów naukowych, jak choćby w przypadku Blumenberga, owocuje wyjściowymi trudnościami w zrozumieniu religijnych źródeł nowoczesnego immanentyzmu i tego, że nie potrzebuje on szoku „eschatologii strachu” ani ekscesu absolutyzmu transcendencji, by się ukształtować - dysponuje własną, niemillenarystyczną semantyką, generując też własne zasoby poznawczych motywacji i strategii działania. Wczesnonowoczesna ,autoasercja człowieka” z II części Die Legitimität der Neųeit (1966) nie była też ani areligijna, ani antyreligijna, a jej religijny charakter nie miał jedynie naskórkowego, językowego charakteru - takie jej określenie mistyfikuje całą społeczno-historyczną złożoność jej materialnej genezy.

${ }^{69}$ Słusznie podkreśla to na przykład w kontekście dawnej debaty Löwith-Blumenberg Jayne Svenungsson (2014). Filozofom bardzo łatwo przychodzi wyizolowanie na potrzeby tezy pojedynczych elementów historii idei, wyrwanie ich ze społeczno-materialnego kontekstu i przypisywanie im globalnej roli.

${ }^{70} \mathrm{R}$ 147.20-22, 209.1-10 i 217.26-28 / FFP, 54, 68, 70.

71 R 141.2-3 / FFU, 74 / FFP, 51. 
przyrody (Jütte 2015, 30 i n.) ${ }^{72}$, jak w przypadku samego Paracelsusa, korzystającego ze wzoru wcześniejszych alchemików, co powtarza się przez cały XVI i XVII wiek, od Tychona de Brahe i Keplera po Newtona włącznie. Okazuje się, że patronem tej nowej religii przyrody i chymii może być nie tylko Salomon, ale nawet sam Mojżesz, schodzacy z Synaju z promieniejąca twarzą i traktowany jak człowiek-Bóg, „drugi Adam” z „odzyskaną chwałą” (Meeks 1970, 354-371) ${ }^{73}$, jak na miedziorycie Franckenberga. Jest nim jednak przede wszystkim wielki potomek Kaina, Tubal-Kain z Rdz 4, 22 - biblijny ojciec metalurgii, „który wykuwał wszelkie narzędzia z miedzi i żelaza”, uznany za patrona chymii i badania materii, nieprzypadkowo przedstawiony przez paracelsystę Dorna jako największy matematyk i astrolog ${ }^{74}$. Jest to wspaniale nowoczesny, chciałoby się powiedzieć - faustyczny, paradoks: egipski kowal-inżynier, reprezentant upadłej ludzkości, patronem nowych mistyków i kosmologów.

Łuk tych wyłonionych mitycznych genealogii - od Tubal-Kaina przez Eliasza po „Chrystiana Rosenkreutza” - legitymizuje siebie jako wspornik nowego, jeszcze kruchego układu odniesienia i wytwarza pozornie nieproporcjonalne społeczne efekty typowe dla nowoczesnych walk na polu polityki wiedzy, tak w świecie protestanckim, jak i katolickim, uruchamiając też łańcuchy antynowoczesnych reakcji. Kościelne ortodoksje i jezuici intensywnie angażowali się w całej Europie w kampanie herezjologiczne, odwołując się do szerokiej palety argumentów: od czysto teologicznych po oskarżenia o przesądy, głupotę, moralne zepsucie i zagrożenie ładu, co sprawia, że przedmiot krytyki został całkowicie przesłonięty ekranem insynuacji, zniekształceń i agresji. Kampanie te, którym towarzyszyło także wyłonienie się walk o naukowo-akademicką ortodoksję ${ }^{75}$, można właśnie w tych aspektach widzieć jako w pewnej mierze bezradne reakcje na tę mutację. Nie wszyscy, jak wcześniej Bruno w Rzymie czy Vanini w Tuluzie, kończą publiczną, brutalna śmiercia z wyroku inkwizycji, ale jest jasne, że trzeba było uważać, na jakim dworze i w jakim mieście się naucza. Określenie „Paracelsista” zaczęło funkcjonować jako inwektywa łącząca oskarżenie o nienaukowość (odrzucenie akademickiego arystotelizmu) z zagrożeniem społecznym chaosem (Moran 2006, 80-83). W Tybindze urządzono w 1622 r. proces wydawcy

72 Jeszcze w końcu XVII w. Newton uważał, że jedynie ponownie odkrywa musteria znane Orfeuszowi, Pitagorasowi, Mojżeszowi czy Salomonowi, dlatego ogromną wagę przywiązywał obok pracy matematycznej do drobiazgowych studiów nad starożytnymi tekstami jako części procesu deszyfracji sekretów natury.

73 Ten zdumiewająco nieortodoksyjny motyw jest dobrym przykładem hybrydyzacji starożytnych tradycji religijnych w sytuacji, gdy nie istniał jeszcze żaden normatywny judaizm.

74 Dorn $(1577,8)$ : „Vulcanicus ille Abraham Tubalchain astrologus \& arithmeticus maximus...”. To samo powtarza na przykład Benedictus Figulus (1608a, fol. VIII) w swojej przedmowie do Pandora magnalium naturalium.

75 W kwestii ideologicznych walk o ortodoksję medyczną nakładających się na religijne napięcie w katolickiej Francji zob. np. Lingo (1986). Przykład wczesnych batalii wokół paracelsjańskiej medycyny i oskarżeń wysuwanych wobec niej o heretycką chrystologię: Bröer (2002). Przykłady teologicznych kontrowersji wokół paracelsjańskiej medycyny i jej niezgodności z arystotelizmem w kontekście konsolidującej się luterańskiej ortodoksji we wczesno-siedemnastowiecznej Danii: Shackelford (2003). 
Eberharda Wilda (Donat 1970), w którego domu znaleziono bogaty ezoteryczny księgozbiór i który nie tylko drukował Andreae’ę i Besolda, ale skupił wokół siebie rozległą sieć czytelników mistycznej i paracelsjańskiej literatury (należeli do nich i Andreae, i Besold, co wypłynęło podczas dochodzenia). Tybingeńscy teologowie z Akademii, przodujący już w atakach na Arndta, podnieśli histeryczną wrzawę na temat grożącego widma rozszerzającej się herezjij ${ }^{76}$ i rewolucji społecznej, porównywalnej z rewoltą chłopską z czasów Lutra czy sukcesem takich spirytualistyczno-komunistycznych wspólnot jak hutteryci na Morawach. Dwa lata później (i sto lat po tym, jak Paracelsus zalecał papieżowi, by się douczał), również w atmosferze histerycznego lęku przed różokrzyżowcami z Niemiec, parlament katolickiego Paryża wypędził z miasta, za radą katolickiego wydziału teologicznego Sorbony, trzech młodych alchemików-atomistów: Antoine’a de Villona, Jeana Bitauda i Étienna de Clave’a, chcących publicznie udowodnić za pomocą eksperymentów, iż filozofia przyrody Arystotelesa jest fałszywa. Zakazał także pod karą śmierci głoszenia nowych doktryn przyrodniczych podważających teologiczne autorytety i sakrament Eucharystii - „cudowną” realność transsubstancjacji (Kahn 2007, 500 i n.). Ten sam wydział teologiczny Sorbony rok później (1625) wydal gwałtowne potępienie i zakaz czytania teoalchemicznego Amphitheatrum sapientiae aeternae Khunratha jako wyjątkowo groźnego i heretyckiego dzieła, ,niebezpiecznego dla wiary”, gwałcącego „najświętsze tajemnice Religii Katolickiej” oraz profanującego Pismo Święte przez pomieszanie go z alchemią i magią (zob. Kahn 2007, 569-593). Jest oczywiste, że katolicka ortodoksja zareagowała na przejmowanie jej pola przez nieprzewidzianą hybrydę: jedne sekrety („mysteria Catholicae Religionis”) zaczęły być wypierane przez inne sekrety (materii i religii przyrody).

Daniel Garber słusznie argumentuje, że histeria ta miała bardzo głębokie podłoże polityczne. Nowe paradygmaty wiedzy i praktyki zagrażały pośredniowiecznemu porządkowi społeczno-politycznemu, otwarte zostały nowe pola batalii wczesnej nowoczesności, których symptomem były kolejne rundy polowań, również państwowych, na heretyków, stąd nie powinno dziwić, że paryskie wystapienie chymików rozpędzała policja, a ekspertyzy w sprawie atomizmu na zamówienie parlamentu dokonywał oburzony wydział teologii (Garber 2002, 135-160). Już ponad dekadę wcześniej katolicki medyk i satyryk Thomas Courval de Sonnet pohukiwał w Paryżu, że paracelsyści, diaboliczna sekta laboratoryjnych „empirystów”, którzy sądzą, że Bóg jest chymikiem, tak jak był nim Tubal-Kain, „powinni zostać ugotowani w tych swoich destylowanych olejach i alembikach, jak gotuje się kapustę

76 Zob. Bubenheimer (1993) oraz Geyer (2001, cz. I, t. 1, 63-78). Szerzej na temat cenzury i wolnomyślicielstwa w tybingeńskiej Akademii Teologicznej: Franz (1977, 123-194). Katoliccy pisarze nie włączyli się początkowo do tego tropienia heretyków, ponieważ traktowali falę ezoteryzmu jako wewnętrzny problem „herezji luterańskiej”. Gilly $(1994,181)$ słusznie zauważa, iż dopiero brukselski proces inkwizycyjny Jana B. van Helmonta w 1634 r. sprawił, iż katolicy zaczęli powszechnie traktować Paracelsusa jako szczególnie niebezpiecznego heretyka. 
w Dauphiné" (Sonnet 1610, 231-232 i 239). W tym samym czasie w Niemczech inny wojowniczy, odznaczony przez papieża jezuita-kontrreformator Hipolit Guarinoni bynajmniej nie satyrycznie grzmiał w swoim rozwlekłym Die Greuel der Verwüstung menschlichen Geschlechts (Rzym 1610), że powinno się ich palić na stosie jako roznoszących choroby trucicieli, podających chemiczne leki na bazie alkoholu zamiast stosowania uznanych metod Galena i Awicenny. To on zadenuncjował w Tyrolu paracelsystę Adama Haslmayra, prekursorskiego propagatora i obrońcę idei Famy Fraternitatis (jeszcze przed jej drukiem), co skończyło się dla tego drugiego prawie pięcioma latami katorgi na galerach (Soukup 2007, 279 i n.). Podobny los spotkał Benedikta Figulusa, który ścigany przez inkwizycję po zaaresztowaniu Haslmayra i konfiskacie jego rękopisów, spędził w więzieniu kilka lat, najprawdopodobniej do listopada 1617 roku, ale wcześniej zdążył przekazać swoje manuskrypty Eglinowi w Marburgu (być może tą drogą tekst Famy Fraternitatis trafił do drukarni w Kassel, wbrew woli Andreae’i).

Obserwujący wydarzenia paryskie Mersenne, ambitny wychowanek jezuitów z La Flèche, w pisanej wtedy i wydanej w 1625 r. La vérité des sciences, atakował z kolei alchemików, kabalistów i paracelsystów jako tych, którzy chcą zgłębiać sekrety przyrody, ignorując arystotelizm, „światło rozumu” (katolickiego) i tomistyczną naukę o analogii. Jego apologetyczne Questiones celeberrimae in Genesim (Paryż 1623), egzegeza Księgi Rodzaju skierowana przeciwko porenesansowemu naturalizmowi i wszelkim heterodoksyjnym filozofiom przyrody zbliżającym do siebie Boga i przyrodę, można czytać jako katolicki odgromnik - przeciwny biegun względem Gutmana, Khunratha i Liber Naturae Arndta (Garber 2002, 139 i n.). Optyka geometryczna jest tam używana do arystotelesowskiej rekonkwisty przeciw paracelsjańskiemu lumen naturae, by utrzymać fizykę $\mathrm{z}$ dala od apokaliptyki i dyskursu odkrywania tajemnic przyrody, gwarantując zarazem, że zdrowe (,geometryczne”) studium tej fizyki wspiera katolicką wiarę i porządek społeczny. Mersenne - dokładnie tak jak jego przyjaciel Kartezjusz - bierze z czasem na cel pojęcie aktywnej czy dynamicznej materii, a główną jego motywacja jest wyeliminowanie go z filozofii przyrody, tak by w grze pozostała tylko materia całkowicie bierna, której ruch modelowany jest przez mechanikę matematyczna (zob. Shapin 2000, 44 i n.). Jego wrogowie to wszyscy przyrodnicyateiści (w tym atomiści), jak w L'impiété des déistes, athées et libertins de ce temps z $1624 \mathrm{r}$. (Mersenne 1975), ale przede wszystkim twórcy nowej alchemicznej religii przyrody, prorocy niewyczerpanych transformacyjnych mocy przyrody - Paracelsus, Bruno, Khunrath czy Croll. Można więc uznać „geometrę” Spinozę za zrealizowany szybko koszmarny sen Mersenne’a, późniejszego kartezjanisty. Batalia od początku zataczała szerokie kręgi - od składu leków i natury metali przez mechanikę i światło po transsubstancjację na katolickich ołtarzach.

Właśnie status materii ma fundamentalne znaczenie jako ontologiczny korelat nowych praktyk eksperymentalnych i polityki, a więc nie jest po prostu marginalnym 
problemem metafizyki po Kartezjuszu. Historia tego pojęcia, wraz z pojęciem przyczynowości, jest jednym z kluczowych wątków nowoczesności - właśnie jako historia prób systematycznej dezaktywacji albo pasywizacji materii w sojuszu z przednowoczesna scholastyką. Fakt, że paracelsyści radykalnie złamali czy odwrócili jej schemat, robiąc z materia prima produktywna prasiłę generująca nieprzebrany gąszcz działań natury, ostro kontrastuje z pozornie rewolucyjnym krokiem Kartezjusza, który zrobił z materia prima stworzona, geometryczna, całkowicie homogeniczna rozciagłość bez nawet śladu własnej aktywności, gwarantując pobożność fizyki w myśl apologetyki Mersenne’a (Spinoza zniszczył później tę gwarancję, używając kartezjańskiego schematu przeciwko niemu samemu, zob. np. Douglas 2015). Praca została czytelnie podzielona między teologię i fizykę, a hybrydy przy rody i ducha usunięte, ale to teologia ze swoim „żywym duchem” zawsze jest po cichu górą w delegacji władzy, co sprawia, że wyrażenie ,żywa przyroda/materia” brzmi odtąd dziwacznie. Z tego jednak powodu zwyczajowe kojarzenie paracelsjańskiego witalizmu z późniejszym filozoficznym idealizmem jest całkowicie błędne, ponieważ - w zgodzie z linią podziału tej pracy - to nowoczesny radykalny idealizm odegrał kluczową rolę w maksymalnej pasywizacji i fenomenalizacji materii w rywalizacji ze swoim rewersem, mechanistycznym materializmem, których obu instynktownie tak nie znosił Goethe. Oba też są w tym sensie bezpośrednim przejawem typowych dla nowoczesności procedur puryfikacji, przemieszczających tylko predykat „realności” między jednym a drugim i ignorujących hybrydy jako „średniowieczny animizm”. W kulminacyjnym momencie biskup Berkeley, sam i zainteresowany alchemia, i gardzący scholastyka, odświeżył „przeciw ateistom i sceptykom” przedparacelsjański, średniowieczny słownik „liter” i „księgi przyrody” w funkcji pobożnościowo-formacyjnej (Bradatan 2006, 57-86), eliminując istnienie materii, zamieniając przyrodę w bierną zjawę („,cienki przezroczysty film”, jak napisał Bergson - Bradatan 2006, 71) i delegując cała aktywność na Boga-Ducha. „Lingua naturae” pracuje tu w reakcyjnym trybie mistyki średniowiecznej, a filozofia przyrody na powrót staje się służąca teologii (Bradatan 2006, 76 i n.). Dla Fichtego z kolei „przyroda”, którą należy u niego brać już w cudzysłów, to nawet nie jedynie zjawisko (Kant), ale raczej transcendentalny grobowiec, hamulec dla życia wybiegającego w nieskończoność Ja: jest „martwa - bezwładny i zamknięty w sobie byt" (Fichte 1806, 29 i n.). Tylko Schellingowi, występującemu w ostrej opozycji do Hegla, udało się wyrwać z tej idealistycznej pułapki przez porzucenie logicznej koncepcji bytu na rzecz ontologii historycznej, co otworzyło drogę marksowskiej dialektyce (Frank 1992). W nowożytnej filozofii materia funkcjonuje więc jako czuły obszar polityki metafizyki, aktywowany po reformacji przez hybrydę w postaci paracelsjańskiej religii, która jako pierwsza naruszyła łącznie wszystkie kluczowe pola władzy - Kościoła, filozofii, uniwersytetu, medycyny i porządku społecznego.

Ta ukryta strona nowoczesności, apokaliptyczna religia przyrody, posiada oczywiście swoją własną dynamikę, ale wewnętrzne napięcie między wymiarem kosmologicznym a tradycyjnie pobożnościowym nadal pozostaje. Prowadzony konsekwentnie projekt 
teoalchemii zawiera - na równi z rywalizującym z nim atomizmem - potencjał rozmontowania doktryn Kościołów, w których przyroda i jej poznanie nie odgrywają żadnej podstawowej roli poza agresywną apologetyką w kreacjonistycznej formule. Ujawnia go już czysto literacka stylizacja postaci arcyreformatora „Chrystiana Rosenkreutza”, który wedle mitu z Famy poznał wiedzę naukowo-przyrodniczą świata arabskiego i jednocześnie, j a k o chymik, lekarz i kosmolog, jest mistykiem zakładającym jakiś zalążek ecclesia spiritualis, nowego apokaliptycznego Kościoła św. Jana na ruinach zdegenerowanego Kościoła rzymskiego. W nowym układzie odniesienia nie ma tu ani żadnej sprzeczności, ani niekonsekwencji, a wręcz przeciwnie - widoczny ma być nawet wspólny kontur „prawdziwego chrześcijaństwa” i „nowych nauk”. Późniejsi chrześcijańscy alchemicy, dłużnicy Dorna, Suchtena, Khunratha czy Eglina twórczo i bez większych problemów radzili sobie aż po Oetingera z tym napięciem, ale uniwersyteccy intelektualiści tacy jak Andreae, wychowany w Tybindze (jak Kepler) na teologicznych wykładach konserwatysty Matthiasa Hafenreffera, czy Besold, wciąż łączący czysto spirytualistyczne idee Weigela i Schwenckfelda z dawną monastyczną mistyka, nabierali wątpliwości, grawitując ku swoim ortodoksjom. Tradycjonalista Besold dokonał nawet około 1630 roku konwersji na rzymski katolicyzm, jak dwieście lat później niektórzy romantycy, najwyraźniej zmęczeni i nieskończoną natura naturans, i gwałtowną nowoczesnościa.

Oscylacja ta, dialektyka rosnącej po dekompozycji arystotelizmu głębokiej niepewności i energicznych naukowych ambicji, religii kościelnych z jednej strony i apokalipsy przyrody z drugiej, jest w ogóle charakterystycznym znakiem wczesnej nowoczesności. Zdaje się nawet, że taka osobowość jak Andreae sama jest w stanie tej oscylacji, jak gdyby mesjański sen o Eliaszu Artyście i „Ojcu C.R.” zaczął mu się wydawać złudą, gdy już został pastorem i kościelnym urzędnikiem. Eliaszowego „Chrystiana Rosenkreutza” zastapił szybko skromna, pietystyczną figurą literacką „Chrystiana Cosmoxenusa” („Chrystiana Obcego Światu”), jak gdyby chciał duszpastersko ograniczać rozmiary antropologicznej inflacji teoalchemii. Zakładane przez niego około 1618 r. z przyjacielem Wilhelmem van der Wense Bractwo Chrześcijańskie (Societas Christiana), któremu patronowała postać starego Arndta i które nie zdążyło się nawet rozwinąć ze względu na rozlewającą się w Europie wojnę trzydziestoletnia, miało być w zamierzeniu Andreae’i opozycją wobec „bezwartościowej zabawy w fikcję Bractwa Różokrzyżowego” (,fictiae Fraternitatis Rosecruciae indignum ludibrium”), jak potem sam to ostro ujął w liście do księcia Augusta Brunszwickiego z 27 czerwca 1642 r. ${ }^{77}$ Typowo pietystyczny charakter Bractwa w duchu Hafenreffera widoczny jest w tekście Invitatio Fraternitatis Christi Andreae’i z 1617 r.: odwołuje się on tu do pierwotnego Kościoła, pierwszych apostołów i niechętnym już okiem patrzy na eksperymentalną chymię i zbyt

\footnotetext{
77 Cyt. w: Dickson $(1998,41)$ - oryginał listu znajduje się w Herzog August Bibliothek w Wolfenbüttel. Na temat podejmowanych później przez Andreae’ę prób pietystycznej reformy luteranizmu zob np.: Brecht (1967, 53-82) i Dickson (1996).
} 
śmiałe idee najnowszej włoskiej filozofii przyrody, która zamiast budować chrześcijańska pobożność, pragnie poznawać sekrety materii będącej „Matką” i „Boginią” (Vanini, Bruno).

Ale kości zostały rzucone i właśnie materia zaczęła wkraczać na scenę jako kluczowa aktorka nowoczesnych batalii. Materia ta nie miała już nic wspólnego z blada, pasywną materia do zewnętrznego kształtowania jako mizernym „modus potentiae” takich neoscholastyków jak Suárez, lecz z bogata, pulsującą ukrytą dynamiką materią mineralną, poddawaną chymicznym badaniom w laboratoriach ludzi takich Eglin, Croll czy przepędzeni z Paryża de Clave i jego uczeń Bitaud. To ta druga była przedmiotem mesjańskiej obietnicy hybrydowego Eliasza nauk, pierwsza zaś - zgodnie z hermetyczną ewangelią Giordana Bruna (Bloch 1985a, 169) - politycznym odpadem układu władzy starego świata.

Ilustracje pochodzą ze zbiorów własnych autora. 


\section{Wykaz literatury}

PSW Paracelsus (Theophrast von Hohenheim). 1922-1933. Sämtliche Werke. Medizinische, naturwissenschaftliche und philosophische Schriften (I. Abteilung, t. 1-14). Hg. von Karl Sudhoff. München-Berlin: R. Oldenbourg.

[Aegidius Gutman]. 1619. Offenbarung GöttlicherMayestat, Darinnen angezeygt wird, Wie Gott der Herr Anfänglich, sich allen seinen Geschöpffen, mit Worten und Wercken geoffenbaret... Hanau: Däsch.

Alexander, Philip S. 1996. „Physiognomy, Initiation and Rank in the Qumran Community”. W Geschichte - Tradition - Reflexion. Festschrift für Martin Hengel zum 70. Geburtstag, red. Hubert Cancik, Hermann Lichtenberger i Peter Schäfer, t. 1. Tübingen: Mohr-Siebeck.

[Andreae, Johann Valentin]. 1616. Theca Gladii Spiritus: sententias quasdem breves vereque philosophicas continens. Strassburg: Lazarus Zetzner.

Andreae, Johann Valentin. 1619. Reipublicae Christianopolitanae descriptio. Strassburg: Lazarus Zetzner.

Andreae, Johann Valentin. 2003. Theca Gladii Spiritus (Johann V. Andreae, Gesammelte Schriften, hg. von Wilhelm Schmidt-Biggemann, t. 5). Bearbeitet, übersetzt, kommentiert von Frank Böhling. Stuttgart-Bad Cannstatt: frommann-holzboog.

[Andreae, Johann Valentin]. 2006. „Fama Fraternitatis, czyli odkrycie Bractwa przesławnego Zakonu R.C. Confessio Fraternitatis". Tłum. Jerzy Prokopiuk. Ars Regia IX/15-16: 50-73. [FFP]

Andreae, Johann Valentin. 2010. Rosenkreuzerschriften (Johann V. Andreae, Gesammelte Schriften, hg. von Wilhelm Schmidt-Biggemann, t. 3). Bearbeitet, übersetzt, kommentiert und eingeleitet von Roland Edighoffer. Stuttgart - Bad Cannstatt: frommann-holzboog. [R]

Arndt, Johann. [1596?]. IKONOGR APHLA. Gründtlicher und Christlicher Bericht von Bildern, ibrem uhrsprung, rechtem gebrauch uñ mißbrauch im alten und newen Testament. Halberstadt: Georg Kote.

Arndt, Johann. 1736. Des Geist- und Trost-reichen Lehrers, Johann Arndts, Weiland Superintendenten des Fürstenthums Lüneburg, Sechs Bücher vom Wabren Christenthum. (...) Nebst dem ParadiesGärtlein (z przedmowa Historische Vorrede Johanna Jakoba Rambacha). Hof: Johann Christoph Leidenfrost.

Augustyn, święty. 1977. O państwie Bos̀mm przeciw poganom ksiag XXII. Tłum. Wiktor Kornatowski. Warszawa: PAX.

Aviles, Alejandro García. 1997. „Alfonso X y el Liber Razielis: imágenes de la magia astral judía en el scriptorium alfonsí". Bulletin of Hispanic Studies LXXIV: 21-39.

Bacon, Franciszek. 1955. Novum Organum. Tłum. Jan Wikarjak. Warszawa: PWN.

Benjamin, Walter. 1991. Über Sprache überhaupt und über die Sprache des Menschen. W Walter Benjamin, Gesammelte Schriften, t. II.1. Frankfurt am Main: Suhrkamp.

Bloch, Ernst. 1985a. Das Materialismusproblem, seine Geschichte und Substan₹. Frankfurt am Main: Suhrkamp.

Bloch, Ernst. 1985b. Atheismus im Christentum. Zur Religion des Exodus und des Reichs. Frankfurt am Main: Suhrkamp.

Bloch, Ernst. 1985c. Experimentum Mundi. Frage, Kategorien des Herausbringens, Praxis. Frankfurt am Main: Suhrkamp. 
Böhme, Jakob. 1682. Mysterium Magnum, Oder Erklärnng über das Erste Buch Mosis, Von der Offenbahrung Göttlichen Worts durch die drey Principia Göttliches Wesens, auch vom Ursprung der Welt und der Schöpffung. Amsterdam: b.w. [Blaeu?].

Bonawentura. 1891. Collationes in Hexaëmeron. W Doctoris Seraphici S. Bonaventurae Opera Omnia, t. V. Quaracchi: Ex Typographia Collegii S. Bonaventurae.

Bradatan, Costica. 2006. The Other Bishop Berkeley: An Exercise in Re-enchantment. New York: Fordham University Press.

Brecht, Martin. 1967. „Johann Valentin Andreaes Versuch einer Erneuerung der Württembergischen Kirche im 17. Jahrhundert”. W Martin Brecht, Kirchenordnung und Kirchenzucht in Württemberg von 16. bis zum 18. Jahrbundert. Stuttgart: Calwer Verlag.

Breger, Herbert. 1984. „Elias Artista - A Precursor of the Messiah in Natural Science”. W Nineteen Eighty-Four: Science between Utopia and Dystopia, red. Everett Mendelsohn i Helga Nowotny. Dordrecht-Boston-Lancaster: D. Reidel.

Bröer, Ralf. 2002. „Friedenspolitik durch Verketzerung. Johannes Crato (1519-1585) und die Denunziation der Paracelsisten als Arianer". Medizinhistorisches Journal 37: 139-182.

Bubenheimer, Ulrich. 1993. „Von der Heterodoxie zur Kryptoheterodoxie. Die nachreformatorische Ketzerbekämpfung im Herzogtum Württemberg und ihre Wirkung im Spiegel des Prozesses gegen Eberhard Wild im Jahre 1622/23”. Zeitschrift der Savigny-Stiftung für Rechtsgeschichte (Kanonistische Abt.) 79: 307-341.

Copenhaver, Brian P. 1990. „Natural Magic, Hermetism, and Occultism in Early Modern Science". W Reappraisals of the Scientific Revolution, red. David C. Lindberg i Robert S. Westman. Cambridge: Cambridge University Press.

Dan, Joseph. 1994. „Three Phases of the History of the Sefer Yezira”. Frankfurter Judaistische Beiträge 21: 7-29.

Delumeau, Jean. 1994. Grzech i strach. Poczucie winy w kulturze Zachodu XIII-XVIII w. Tłum. Adam Szymanowski. Warszawa: PAX - Volumen.

Dickson, Donald R. 1996. „Johann Valentin Andreae’s Utopian Brotherhoods”. Renaissance Quarterly 49: 760-802.

Dickson, Donald R. 1998. The Tessera of Antilia: Utopian Brotherhoods and Secret Societies in the Early Seventeenth Century. Leiden-Boston-Köln: Brill.

Donat, Dietrich. 1970. Eberhard Wild, ein Drucker mystisch-spiritualistischer Werke zu Beginn des 17. Jabrbunderts. W Slavische Barockliteratur I (Forum Slavicum, t. 23), red. Dmitrij Tschižewskij. München: Wilhelm Fink.

Dorn, Gerhard. 1577. Aurora Thesaurusque Philosophorum, Theophrasti Paracelsi, Germani Philosophi, \& Medici cunctis omnibus accuratissimi. Bazylea: b.w. [Thomas Guarinus?].

Douglas, Alexander X. 2015. Spinoza and Dutch Cartesianism: Philosophy and Theology. Oxford: Oxford University Press.

Eamon, William. 1994. Science and the Secrets of Nature: Books of Secrets in Medieval and Early Modern Culture. Princeton, NJ: Princeton University Press.

Fama Fraternitatis Oder Entdeckung der Brüderschafft des löblichen Ordens dess Rosenkreutzes. Beneben der Confession Oder Bekantnuss derselben Fraternitet, an alle Gelehrte und Häupter in Europa geschrieben. 1615. Danzig (Gdańsk): Andreas Hünefeld. [FFG]

Fichte, Johann Gottlieb. 1806. Ueber das Wesen des Gelehrten, und seine Erscheinungen im Gebiete der Freibeit. In öffentlichen Vorlesungen, gehalten zu Erlangen, im Sommer-Halbjabre 1805. Berlin: Himburgische Buchhandlung. 
Figulus, Benedictus. 1608a. Pandora magnalium naturalium aurea et benedicta, De Benedicto Lapidis Philosoph. Mysterio. Strassburg: Lazarus Zetzner.

Figulus, Benedictus. 1608b. Rosarium novum olympicum et benedictum, ein newer Gebenedeyter philosophischer Rosengart (...). Pars prima. Bazylea: B. Figulus.

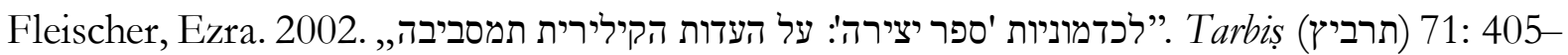
432.

Fodor, Alexander. 2006. „An Arabic Version of Sefer ha-Razim”. Jemish Studies Quarterly 13: 412-427.

Foucault, Michel. 2000. Stowa i rzeczy. Archeologia nank humanistycznych, t. I. Tłum. Tadeusz Komendant. Gdańsk: Słowo/obraz terytoria.

Frank, Manfred. 1992. Der unendliche Mangel an Sein. Schellings Hegelkritik und die Anfänge der Marxschen Dialektik. 2., stark erweiterte und überarbeitete Auflage. München: Wilhelm Fink Verlag.

Franz, Günther. 1977. „Bücherzensur und Irenik: die theologische Zensur im Herzogtum Württemberg in der Konkurrenz von Universität und Regierung”. W Theologen und Theologie an der Universität Tübingen. Beiträge zur Geschichte der Evangelisch-Theologischen Fakultät, red. Martin Brecht. Tübingen: Mohr.

Garber, Daniel. 2002. „Defending Aristotle / Defending Society in Early 17th Century Paris". W Wissensideale und Wissenskulturen in der frühen Neuzeit, red. Wolfgang Detel i Claus Zittel. Berlin: Akademie-Verlag.

Geyer Hermann. 2001. Verborgene Weisheit. Johann Arndt's „Vier Büchervom wabren Christentum” als Programm einer spiritualistisch-hermetischen Theologie (Arbeiten zur Kirchengeschichte, t. 80/ III), 2 t.. Berlin-New York: Walter de Gruyter.

Gilly, Carlos. 1986. Johann Valentin Andreae 1586-1986. Die Manifeste der Rosenkreuzerbruderschaft. Katalog einer Ausstellung in der Bibliotheca Philosophica Hermetica. Amsterdam: BPH.

Gilly, Carlos. 1994. „»Theophrastia Sancta«. Der Paracelsismus als Religion im Streit mit den offiziellen Kirchen”. W Analecta Paracelsica. Studien zum Nachleben Theophrastvon Hohenheims im deutschen Kulturgebiet derfrühen Neuzeit, red. Joachim Telle. Stuttgart: Franz Steiner Verlag.

Gilly, Carlos, red. 1995. Cimelia Rhodostaurotica. Die Rosenkreuzer im Spiegel der zwischen 1610 und 1660 entstandenen Handschriften und Drucke. Ausstellung der Bibliotheca Pbilosopbica Hermetica Amsterdam und der Herzog August Bibliothek. Wolfenbüttel. Amsterdam: In de Pelikaan.

Gilly, Carlos. 1997. „Johann Arndt und die »dritte Reformation« im Zeichen des Paracelsus”. Nova Acta Paracelsica. Neue Folge 11: 60-77.

Gilly, Carlos. 2000. „Das Bekenntnis zur Gnosis von Paracelsus bis auf die Schüler Jacob Böhmes". W From Poimandres to Jacob Böhme: Gnosis, Hermetism and the Christian Tradition, red. Roelof van den Broek i Cis van Heertum. Amsterdam: In de Pelikaan.

Gilly, Carlos. 2002. „Abraham von Franckenberg und die Rosenkreuzer. Zur Datierung der Tabula Universalis Theosophica Mystica et Cabalistica von 1623". W Rosenkreuzals europäisches Phänomen im 17. Jahrhundert, red. Bibliotheca Philosophica Hermetica. Amsterdam: In de Pelikaan.

Greyerz, Kaspar von. 1999. „Alchemie, Hermetismus und Magie. Zur Frage der Kontinuitäten in der wissenschaftlichen Revolution". W Im Zeichen der Krise. Religiosität im Europa des 17. Jahrbunderts, red. Hartmut Lehmann i Anne-Charlott Trepp. Göttingen: Vandenhoeck \& Ruprecht. 
Hanegraaff, Wouter J. 2012. Esotericism and the Academy: Rejected Knowledge in Western Culture. Cambridge: Cambridge University Press.

Hannaway, Owen. 1986. „Design and the Aim of Science: Andreas Libavius versus Tycho Brahe". Isis 77: 586-610.

Hapelius, Nicolaus Niger (Anagrammatizomenos). 1612. Cheiragogia Heliana de Auro Philosophico necdum cognito. Marburg: Rudolf Hutwelcker.

Hardt, Michael i Antonio Negri. 2005. Imperium. Tłum. Sergiusz Ślusarski i Adam Kołbaniuk. Warszawa: WAB.

Heine, Heinrich. 1997. Z driejów religii i filozofii w Niemczech. Tłum. Tadeusz Zatorski. Kraków: Nomos.

Henry, John. 2008. „The Fragmentation of Renaissance Occultism and the Decline of Magic". History of Science 46: 1-48.

Heyd, Michael. 1995. „Be Sober and Reasonable”: The Critique of Enthusiasm in the Seventeenth and Early Eighteenth Centuries. Leiden-New York-Köln: Brill.

Idel, Moshe. 1990. Golem: Jewish Magical and Mystical Traditions on the Artificial Anthropoid. Albany: State University of New York Press.

Idel, Moshe. 1998. „Saturn and Sabbatai Tzevi: A New Approach to Sabbateanism”. W Toward the Millenium: Messianic Expectations from the Bible to Waco, red. Peter Schäfer i Mark R. Cohen. Leiden: Brill.

Jonston, Jan. 1634. Naturae constantia: seu Diatribe, in qua ... Mundum, nec ratione sui totius, nec ratione partium, universaliter \& perpetuo in pejus ruere, ostenditur. Amsterdam: Johannes Janssonius. (Wyd. pol.: O stałości natury, przeł. Maria Stokowska, PWN, Warszawa 1960).

Jütte, Daniel. 2015. The Age of Secrecy: Jews, Christians, and the Economy of Secrets, 1400-1800. New Haven-London: Yale University Press.

Kahn, Didier. 2007. Alchimie et Paracelsisme en France à la fin de la Renaissance (1567-1625). Genève: Libraire Droz.

Kepler, Ioannes. 1596. Prodromus Dissertationum Cosmographicarum, continens Mysterium Cosmographicum... Tübingen: Georgius Gruppenbachius.

Klein, Wolf Peter, red. 1994. Sefer Jezirah. Übersetzt und kommentiert von Guillaume Postel. Neudruck der Ausgabe Paris 1552 (Clavis Pansophiae, t. 1). Stuttgart-Bad Cannstatt: frommann-holzboog.

Kooij, Pleun van der i Carlos Gilly, red. 1998. Fama Fraternitatis. Das Urmanifest der Rosenkreuzer Bruderschaft, zum ersten Mal nach den Manuskripten bearbeitet, die vor dem Erstdruck von 1614 enstanden sind. Haarlem: Rozekruis Pers. [FFU]

Kühlmann, Wilhelm i Joachim Telle. 1996. Einleitung. W Crollius, Oswaldus, De signaturis internis rerum. Die lateinische editio princeps (1609) und die deutsche Erstübersetzung (1623) (Heidelberger Studien zur Naturkunde der frühen Neuzeit, t. 5), hg. und eingel. von Wilhelm Kühlmann i Joachim Telle. Stuttgart: Franz Steiner Verlag.

Kuntz, Marion L. 1981. Guillaume Postel: Prophet of the Restitution of All Things. His Life and Thought. The Hague: Martin Nijhoff.

Libavius, Andreas. 1610. De universitate, et originibus rerum conditarum contemplatio singularis, theologica, et philosophica. Frankfurt nad Menem: Petrus Kopff.

Libavius, Andreas. 1615. Examen philosophiae novae, quae veteri abrogandae opponitur. Frankfurt nad Menem: Petrus Kopff. 
Libavius, Andreas. 1616. Woblmeinendes Bedencken von der Fama, und Confession der Brüderschafft des RosenCreutzes, eine UniversalReformation, und Umbkehrung der gantzen Welt vor dem Jüngsten Tag, zu einem irrdischen Paradey $\beta$. Frankfurt nad Menem: Petrus Kopff.

Liber de Creatione, cabalistinis, hebraice Sepher Iezira, authore Abrahamo. 1587. W Artis Cabalisticae: hoc est, reconditae theologiae et philosophiae scriptorum: tomus I. (...) Ex D. Ioannis Pistorii, Nidani, Med. D. et Marchionum Badensium Consiliarij Bibliotheca. Bazylea: Sebastian Henricpetri.

Lingo, Alison K. 1986. „Empirics and Charlatans in Early Modern France: The Genesis of the Classification of the »Other« in Medical Practice". Journal of Social History 19: 583 603.

Lippmann, Edmund O. von. 1920. „Der Stein der Weisen und Homunculus, zwei alchemistische Probleme in Goethes Faust'. Chemiker-Zeitung 44/31: 213-216.

Maier, Michael. 1618. Atalanta Fugiens, hoc est, Emblemata Nova de Secretis Naturae chymica. Oppenheim: Hieronymus Gallerus.

McGuire, James E., i Piyo M. Rattansi. 1966. „Newton and the »Pipes of Pan«.” Notes and Records of the Royal Society of London 21: 108-143.

Meeks, Wayne. 1970. „Moses as God and King”. W Religions in Antiquity: Essays in Memory of Erwin Ramsdell Goodenough, red. Joseph Neusner, Leiden: Brill.

Mersenne, Marin. 1975. L'impiété des déistes, athées et libertins de ce temps. Faksimile-Neudruck der Ausgabe Paris 1624. Stuttgart-Bad Cannstatt: Friedrich Frommann Verlag.

Metzger, Bruce M. 2001. The Early Versions of the New Testament: Their Origin, Transmission and Limitations. Oxford: Oxford University Press.

Moran, Bruce T. 2006. Distilling Knowledge: Alchemy, Chemistry, and the Scientific Revolution. Cambridge: Harvard University Press.

Newman, William R. 1999. „Alchemical Symbolism and Concealment: The Chemical House of Libavius". W The Architecture of Science, red. Peter Galison, Emily Thompson. Cambridge - London: The MIT Press.

Pagel, Walter. 1961. „,The Prime Matter of Paracelsus”. Ambix IX(3): 117-135.

Pagel, Walter. 1979. „Paracelsus als »Naturmystiker«”. W Epochen der Naturmystik. Hermetische Tradition im wissenschaftlichen Fortschritt, red. Antoine Faivre, RolfCh. Zimmermann. Berlin: Erich Schmidt Verlag.

Paracelsus. 1924a. Das Buch Paragranum (Letzte Bearbeitung in vier Abschnitten, 1530). W PSW, t. 8.

Paracelsus. 1924b. Vorrede und erste beide Bücher des Paragranum (1530). W PSW, t. 8.

Paracelsus. 1925. Die drei (vier) Bücher des Opus Paramirum (St. Gallen 1531). W PSW, t. 9.

Paracelsus. 1928a. Labyrinthus medicorum errantium. Vom Irrgang der Aerzte (1537/38). W PSW, t. 11.

Paracelsus. 1928b. Die 9 Bücher De Natura rerum (1537?). W PSW, t. 11.

Paracelsus. 1929. Astronomia Magna oder die ganze Philosophia sagax der grossen und kleinen Welt (1537/38). W PSW, t. 12.

Paracelsus. 1931. Liber de Imaginibus. W PSW, t. 13.

Philochemicus, Heliophilus. 1608. Disquisitio de Helia Artista, in qua de metallorum transformatione, adversus Hagelii \& Pererii Jesuitarum opiniones, evidenter \&o solide disseritur. Editio postrema correctior \& melior. Marburg: Rudolf Hutwelcker. 
Postel, Guillaume. 1552. Abrahami Patriarchae Liber Jezirah, sive Formationis Mundi: patribus quidem Abrahami tempora praecedentibus revelatus, sed ab ipso etiam Abrahamo expositus Isaaco (...). Vertebat ex hebraeis et commentariis illustrabat 1551. Parisiis: G. Postello.

Prinke, Rafał T. 2014. Zwodniçy ogród btẹdów. Piśmiennictwo alchemiczne do końca XVIII wieku. Warszawa: Wydawnictwo Instytutu Historii Nauki PAN.

Rowland, Christopher. 1982. The Open Heaven: A Study of Apocalyptic in Judaism and Early Christianity. New York: SPCK.

Schmidt-Biggemann, Wilhelm. 2004. Philosophia Perennis: Historical Outlines of Western Spirituality in Ancient, Medieval and Early Modern Thought (Archives Internationales d'Histoire des Idées, t. 189). Dordrecht: Springer.

Schneider, Hans. 2006. „Johann Arndt als Paracelsist”. W Hans Schneider, Der fremde Arndt. Studien zur Leben, Werk und Wirkung Johann Arndts (1555-1621). Göttingen: Vandenhoeck \& Ruprecht.

Secret, François. 1969. „Sur quelques traductions du Sefer Rąï'el'. Revue des Études Juives CXXVIII: 223-245.

Sepher ha-Razim (םפר הרזים). 1966. Wyd. Mordecai Margalioth. Jerozolima: Yediot Ahronot (w jęz. hebrajskim).

Shackelford, Jole. 1993. „'Tycho Brahe, Laboratory Design, and the Aim of Science: Reading Plans in Context". Isis 84: 211-230.

Shackelford, Jole. 2003. „Paracelsianism and the Orthodox Lutheran Rejection of Vital Philosophy in Early Seventeenth-Century Denmark". Early Science and Medicine 8: 210_ 252.

Shapin, Steven. 2000. Rewolucja naukowa. Tłum. Stefan Amsterdamski. Warszawa: Prószyński i S-ka.

Sonnet, Thomas. 1610. Satyre contre les charlatans, et pseudomedicins empyriques. Paris: Jean Millot.

Soukup, RudolfW. 2007. Chemie in Österreich, t. I: Bergbau, Alchemie und frühe Chemie. WienKöln- Weimar: Böhlau Verlag.

Stuckrad, Kocku von. 2010. Locations of Knowledge in Medieval and Early Modern Europe: Esoteric Discourse and Western Identities. Leiden-Boston: Brill.

Svenungsson, Jayne. 2014. „A Secular Utopia: Remarks on the Löwith-Blumenberg Debate”. W Jewish Thought, Utopia and Revolution, red. Elena Namli, Jayne Svenungsson, Alana Vincent. Amsterdam-New York: Rodopi.

Szulakowska, Urszula. 2000. The Alchemy of Light: Geometry and Optics in Late Renaissance Alchemical Illustration. Leiden-Boston-Köln: Brill.

Telle, Joachim. 1994. „Paracelsus als Alchemiker”. W Paracelsus und Sal々burg (14. Ergänzungsband der Mitteilungen der Gesellschaft für Salzburger Landeskunde), red. Heinz Dopsch i Peter F. Kramml. Salzburg: Anton Pustet.

Travaglia, Pinella. 2001. Una cosmologia ermetica. Il Kitāb sirr al-halīqa / De secretis naturae. Napoli: Liguori Editori.

Trepp, Anne-Charlott. 1999. „Religion, Magie und Naturphilosophie. Alchemie im 16. und 17. Jahrhundert”. W Im Zeichen der Krise. Religiosität im Europa des 17. Jahrbunderts, red. Hartmut Lehmann i Anne-Charlott Trepp. Göttingen: Vandenhoeck \& Ruprecht.

Trepp, Anne-Charlott. 2006. „Zur Differenzierung der Religiositätsformen im Luthertum des 17. Jahrhunderts und ihrer Bedeutung für die Deutungen von Natur". Pietismus und Neuzeit. Ein Jahrbuch zur Geschichte des neueren Protestantismus 32: 37-56. 
Tzvi Langermann, Y. 2002. „On the Beginning of Hebrew Scientific Literature and on Studying History Through »Maqbilot«(Paralells)". Aleph 2: 169-189.

Vajda, Georges. 1954. Juda ben Nissim ibn Malka, philosophe juif marocain. Paris: Hesperis.

Vickers, Brian. 1984. „Analogy versus Identity: The Rejection of Occult Symbolism, 1580_ 1680". W Occult and Scientific Mentalities in the Renaissance, red. Brian Vickers. CambridgeLondon-New York: Cambridge University Press.

Walton, Michael T. 2015. „The Chemical Philosophy and Kabbalah: Pantheus, Khunrath, Croll, and the Treasures of the Oratory and the Laboratory". W Bridging Traditions: Alchemy, Chemistry and Paracelsian Practices in the Early Modern Era, red. Karen H. Parshall, Michael T. Walton i Bruce T. Moran. Kirksville/MO: Truman State University Press.

Wasserstrom, Steven M. 1993. , Sefer Yeșirah and Early Islam: A Reappraisal”. Journal of Jewish Thought and Philosophy 3: 1-30.

Wasserstrom, Steven M. 2002. „Further Thoughts on the Origins of Sefer Yeșirah”. Aleph 2: 201-221.

Webster, Charles. 1992. Od Paracelsusa do Newtona. Magia i powstanie nowożytnej nanki. Tłum. Klara Kopcińska i Artur Zapałowski. Warszawa: IFiS PAN.

Webster, Charles. 2002. The Great Instauration: Science, Medicine and Reform, 1626-1660, wyd. 2. Frankfurt am Main: Peter Lang.

Weiss, Tzahi. 2013. ,The Reception of Sefer Yetsirah and Jewish Mysticism in the Early Middle Ages". The Jewish Quarterly Review 103(1): 26-46.

Wilkinson, Robert J. 2007. Orientalism, Aramaic and Kabbalab in the Catholic Reformation: The First Printing of the Syriac New Testament. Leiden-Boston: Brill.

Wollgast, Siegfried. 1993. Philosophie in Deutschland zwischen Reformation und Aufklärung 1550_ 1650, wyd. 2. Berlin: Akademie-Verlag.

Woszczek, Marek. 2007. „Wolność, »zakażony korzeń« i machina mundi (Leibniz - Schelling Goethe)". W Wolność-szkice i studia, red. Piotr Orlik. Poznań: Wyd. Naukowe IF UAM.

Woszczek, Marek. 2009. „Newton-alchemik i imaginacyjne drogi fizyki”. W W kregu filozofii nauki, kultury i społeczeństwa, red. Tadeusz Buksiński i Elżbieta Pakszys. Poznań: Wyd. Naukowe IF UAM. 
Marek Woszczek - filozof, adiunkt w Zakładzie Filozofii Nauki Instytutu Filozofii UAM w Poznaniu. Zajmuje się ontologia przyrody i filozofia fizyki. Prowadzi także badania nad wybranymi problemami historii i filozofii religii, w szczególności historią interakcji dyskursów religijno-teologicznych i naukowo-przyrodoznawczych, od wczesnonowożytnej nauki po romantyczną Naturphilosophie. Autor książki Platonic Wholes and Quantum Ontology, Frankfurt am Main 2015 (1. wyd. pol.: Ukryta catość prayrody a mikrofizylka, Poznań 2010). Laureat nagrody naukowej Prezesa Rady Ministrów (2010).

\title{
DANE ADRESOWE:
}

Instytut Filozofii UAM

ul. Szamarzewskiego 89c

60-568 Poznań

EMAIL: marwos@amu.edu.pl

CYTOWANIE: Woszczek, Marek. 2016. Eliasz nauk. Apokaliptyka, paracelsjańska mistyka przyrody i narodziny nowoczesności (część druga). Praktyka Teoretycz̧na 1(19): 172-216.

DOI: $10.14746 /$ prt.2016.1.9

\section{AUTHOR: Marek Woszczek}

TITLE: Elijah of the Arts: Apocalypticism, Paracelsian Mysticism of Nature, and the Origins of Modernity

\begin{abstract}
The myth of $[\mathrm{H}]$ Elias Artista (or 'Elijah of the Arts') is one of the most interesting components of the rich 16th-century Paracelsian tradition from the margins of the post-Reformation orthodoxy. It signals a surprising development within the Christian apocalyptic tradition since 'Helias artium chymicarum', the messianic Experimentator as a human Christ-like figure and an end-of-time counterpart of the biblical blacksmith Tubal-cain, is an original transformation of the Jewish apocalyptic Elijah in a context of the early modernity on the eve of the Thirty Years War. That figure is an example from the broader domain of the Paracelsian 'theoalchemy' (Telle), which may be construed as a typically modern hybrid in the Latourian sense. Furthermore, in order to understand the peculiar post-Reformation phenomenon of the mysticism of nature (Dorn, Khunrath, Gutman, Arndt, Boehme, and others), which is in stark tension with orthodox theologies, it is necessary to take into account that it was a product of the new powerful intellectual formation which can be dubbed the nature (or cosmological) apocalypticism.
\end{abstract}


It is claimed that that 'vertical' (non-eschatological) apocalypticism of nature is an early modern form of the ancient Jewish apocalyptic tradition transformed under the new socialcultural conditions into a formula of the 'learning the secrets of nature' in a complex process of renegotiating the power relations, and it produced the ample resource of the cognitive motivations for experimental activity, quite independently of the gradually waning millenarian affects. Thus, that transformation is important for understanding the religious early modernity and its immanentist, activist attitudes and getting beyond the one-dimensional discourses of the secularization paradigm, which obliterates or ignores the 'vertical' axis of apocalypticism and fixes itself upon the horizontal (millenarian) dimension while (re)constructing the criticized unpicturesque 'irreligion of progress' (Löwith). Early modernity could be better understood as a diffused turn (effect) associated with the innovative material (e.g. medical or chemical) practices and their new conceptualisations of matter and knowledge, where philosophy, theology, science of matter and social revolt seem inseparable. The myth of the Elijah of the Arts, contrary to a superficial secularization interpretation, is one of the symptoms of the growing process of 'de-eschatologization' through the alternative direction of apocalypticism, i.e., shifting an interest to nature and matter as the religious objects available to exploration, which produced the new power conflicts typical of modernity but also the 'laboratory' as a space of unveiling that which is hidden in nature.

KEYWORDS: early modernity, nature (cosmological) apocalypticism, myth of Elias Artista, mysticism of nature, Paracelsian alchemy, matter, pantheism, ontology of expression 